\title{
The evaluation of the potential of global data products for snow hydrological modelling in ungauged high-alpine catchments
}

\author{
Michael Weber ${ }^{1}$, Franziska Koch ${ }^{2}$, Matthias Bernhardt ${ }^{2}$, and Karsten Schulz ${ }^{2}$ \\ ${ }^{1}$ Department of Geography, Ludwig-Maximilians-Universität, Munich, Germany \\ ${ }^{2}$ Institute for Hydrology and Water Management, University of Natural Resources and Life Sciences, Vienna, Austria
}

Correspondence: Franziska Koch (franziska.koch@boku.ac.at)

Received: 27 June 2020 - Discussion started: 13 August 2020

Revised: 22 April 2021 - Accepted: 24 April 2021 - Published: 27 May 2021

\begin{abstract}
For many ungauged mountain regions, global datasets of different meteorological and land surface parameters are the only data sources available. However, their applicability in modelling high-alpine regions has been insufficiently investigated so far. Therefore, we tested a suite of globally available datasets by applying the physically based Cold Regions Hydrological Model (CRHM) for a 10year (September 2000-August 2010) period in the gauged high-alpine Research Catchment Zugspitze (RCZ), which is $12 \mathrm{~km}^{2}$ and located in the European Alps. Besides meteorological data, snow depth is measured at two stations. We ran CRHM with a reference run with in situ-measured meteorological data and a $2.5 \mathrm{~m}$ high-resolution digital elevation model (DEM) for the parameterization of the surface characteristics. Regarding different meteorological setups, we used 10 different globally available datasets (including versions of ERA, GLDAS, CFSR, CHIRPS) and additionally one transferred dataset from a similar station in the vicinity. Regarding the different DEMs, we used ALOS (Advanced Land Observing Satellite) and SRTM (Shuttle Radar Topography Mission) (both $30 \mathrm{~m}$ ) as well as GTOPO30 (1 km). The following two main goals were investigated: (a) the reliability of simulations of snow depth, specific snow hydrological parameters and runoff with global meteorological products and (b) the influence of different global DEMs on snow hydrological simulations in such a topographically complex terrain. The range between all setups in mean decadal temperature is high at $3.5^{\circ} \mathrm{C}$ and for the mean decadal precipitation sum at $1510 \mathrm{~mm}$, which subsequently leads to large offsets in the snow hydrological results. Only three meteorological setups, the reference, the transferred in situ dataset and the CHIRPS dataset, substituting precipitation only, showed
\end{abstract}

agreeable results when comparing modelled to measured snow depth. Nevertheless, those setups showed obvious differences in the catchment's runoff regime and in snow depth, snow cover, ablation period, the date, and quantity of maximum snow water equivalent in the entire catchment and in specific parts. All other globally available meteorological datasets performed worse. In contrast, all globally available DEM setups reproduced snow depth, the snow hydrological parameters and runoff quite well. Differences occurred mainly due to differences in radiation model input due to different spatial realizations. Even though SRTM and ALOS have the same spatial resolution, they showed considerable differences due to their different product origins. Despite the fact that the very coarse GTOPO30 DEM performed relatively well on the catchment mean, we advise against using this product in such heterogeneous high-alpine terrain since small-scale topographic characteristics cannot be captured. While global meteorological data are not suitable for sound snow hydrological modelling in the RCZ, the choice of the DEM with resolutions in the decametre level is less critical. Nevertheless, global meteorological data can be a valuable source to substitute single missing variables. For the future, however, we expect an increasing role of global data in modelling ungauged high-alpine basins due to further product improvements, spatial refinements and further steps regarding assimilation with remote sensing data.

\section{Introduction}

Worldwide, the vast majority of catchments are ungauged, which means that within these basins continuous data of in 
situ-measured meteorological and snow hydrological parameters are not available (Abimbola et al., 2017; Blöschl et al., 2013). This is critical, as many ungauged basins need detailed information on their hydrological cycle and storages to optimize water usage schemes or hazard management (Merwade et al., 2008; Hirsch and Costa, 2004; Abimbola et al., 2017). However, the best available data for hydrological modelling are in situ hydro-meteorological station recordings like, for example, temperature, precipitation or runoff and data from snow gauges, where the latter is particularly important in high-alpine areas (Fekete et al., 2015). A broad range of mountain catchments, which contribute snow melt as major runoff component to the rivers, are affected by the lack of sufficient instrumentation and data (Hrachowitz et al., 2013; Wortmann et al., 2018; Zhang et al., 2015; Dussaillant et al., 2012). This is problematic, as mountain catchments are highly relevant for local water supply and that of the adjacent lowlands (Bandyopadhyay et al., 1997; Viviroli et al., 2011; Meybeck et al., 2001; Wesemann et al., 2018; Mauser and Prasch, 2016; Zhang et al., 2015; Koch et al., 2011; Huggel et al., 2015).

The seasonal snow cover in mountains plays a major role for the alpine water cycle (Barnett et al., 2005; Huss et al., 2017; Brown and Mote, 2008). For example, Beniston (2012) shows for the Rhine and the Rhone basins that snow is the biggest single contributor to seasonal runoff. Worldwide, Barnett et al. (2005) estimate that one-sixth of the population lives within snowmelt-dominated catchments, and in Asia or North America, the share of meltwater from snow and ice at total runoff is estimated to be more than $30 \%$ (Huss et al., 2017). Nonetheless, the instrumentation of high-alpine catchments for meteorological, snow or runoff measurements is sparse. Possible reasons are the complex topography and the remoteness of mountain regions, which makes access and logistics more difficult, labour-intensive and expensive. Further issues are the lack of funds for installation and maintenance as well as too few or untrained personnel (Sabatini, 2017; Whitfield et al., 2013; Tauro et al., 2018). In particular, snow water equivalent (SWE) measurements, representing the amount of stored water, are very valuable for hydrological applications. However, SWE measurements are largely underrepresented in many regions worldwide compared to snow depth measurements (Haberkorn, 2019). Nevertheless, in situ SWE measurements are increasingly facilitated by continuous improvements of existing methods like snow pillows or scales and developments of new methods like snow sensing with Global Navigation Satellite System (GNSS) signals and cosmic rays (Koch et al., 2019; Schattan et al., 2017).

Satellite-based remote sensing serves as a valuable option or additive to derive information on the snow cover and its properties. This is particularly true for snow cover extent products derived with optical sensors despite data gaps due to cloud coverage as their major drawback (Hall et al., 2002; Gascoin et al., 2019). Contrarily, the derivation of snow depth or SWE, based on satellite remote sensing products, is still not sufficiently solved, in particular for complex terrain in high-alpine environments (Lettenmaier et al., 2015; Bormann et al., 2018). Active microwave products might be severely affected by relief displacements caused by layover and foreshortening, and passive microwave products are too low in their spatial resolution for alpine regions (Vuyovich et al., 2014; Shi and Dozier, 1997, 2000). However, currently the derivation of snow properties via space-borne remote sensing is rapidly developing, e.g. by launching new sensors, enhancing the spatial and temporal resolution, and the development of new algorithms. Those methods already show promising results in mountainous regions (Rott et al., 2014; Notarnicola, 2020; Lievens et al., 2019). Moreover, numerous promising airborne or combined in situ, airborne and space-borne approaches have been developed in the last decades (Currier et al., 2019; Adams et al., 2018; Kim et al., 2018; Bühler et al., 2015), but they are still not possible to perform in many mountain areas due to their remoteness and cost issues. Therefore, until now, the snow cover cannot be entirely described by solely relying on remote sensing techniques.

The sparse data availability was one of the reasons for the International Association of Hydrological Sciences (IAHS) to launch the Prediction in Ungauged Basins (PUB) initiative in 2003 (Pomeroy et al., 2013; Blöschl et al., 2013). Research foci have been various regionalization techniques such as in situ data transferred from other catchments (Liu et al., 2013), using gridded datasets based on remote sensing or atmospheric models as well as using hybrid data that combine in situ measurements, remote sensing and atmospheric modelling (Kahl et al., 2013; Pomeroy et al., 2013). Regarding atmospheric models, two main representatives of hybrid data are reanalysis and land data assimilation products (Poli et al., 2016; Rodell et al., 2004). Both represent a consistent, multi-year description of the atmospheric state. Precipitation data are especially afflicted by errors and need to be bias corrected, which requires additional effort (Piani et al., 2010; Smiatek et al., 2009; Christensen et al., 2008; Muerth et al., 2013) and is difficult to achieve without field measurements (Fatichi et al., 2016; Gampe et al., 2019).

However, globally available atmospheric model, hybrid or remote sensing products are still often the only available meteorological model input data source for ungauged catchments. Moreover, publicly available data are a great opportunity for hydrologists with little budget available for data acquisition. This applies to countries with already limited financial resources (Feki et al., 2017; van de Giesen et al., 2014) and affects a large number of remote mountain catchments. The same is true for land surface information, such as altitude, aspect or slope, which is needed for model parameterization. This information influences a wide range of model routines like the calculation of radiation or the extrapolation of station-recorded temperature to other parts of the catchment. With the generation of digital elevation mod- 
els (DEMs) from remote sensing products, this information becomes globally available since the late 20th century (Farr et al., 2007; USGS, 1996). The largest differences amongst satellite-derived DEM products occur due to different viewing angles of the applied sensors and the spatial resolutions of the product. Individual high-resolution topographic information acquired, for example, by lidar is very rare.

Given these limitations, we tested the performance of global data products for snow hydrological modelling. Two explicit research questions were guiding our analysis:

- Is it possible to use globally available meteorological data products to reliably simulate snow depth, specific snow hydrological parameters and runoff in high-alpine catchments?

- What impact have DEM products with different spatial resolutions on snow hydrological simulations in complex topography?

To answer the first question, we investigated globally and publicly available meteorological driver data from the Climate Forecast System Reanalysis (CFSR), different versions of the Global Land Data Assimilation System (GLDAS), ERA-20C as well as ERA5 and ERA5-Land datasets and precipitation information from the Climate Hazards group Infrared Precipitation with Stations (CHIRPS). Those data are referred to as hybrid data. There have already been studies in several regions to test such data products (Förster et al., 2016; Fuka et al., 2013; Essou et al., 2016, 2017; Casson et al., 2018) but not, as far as we know, solely and explicitly on high-alpine catchments. Some of these studies showed good results, whilst others underlined the importance of adapting the data to regional conditions. In addition, we evaluate the performance of a transfer from in situ-measured data at a similar site as suggested by the PUB initiative (Liu et al., 2013). Regarding our second question, we investigated possible differences in model performance resulting from different topographic characteristics originating from globally and publicly available DEMs with different spatial resolutions and sensing techniques. Therefore, we chose three commonly used DEMs GTOPO30, ALOS (Advanced Land Observing Satellite) and SRTM (Shuttle Radar Topography Mission) for this study.

We conducted our study in the gauged, well-known and snow-dominated high-alpine Research Catchment Zugspitze (RCZ) in the European Northern Calcareous Alps (Hürkamp et al., 2019; Härer et al., 2018; Bernhardt et al., 2018), which is one of the best instrumented high-alpine catchments worldwide. This allows for an evaluation with in situ-measured meteorological and snow depth data as well as in situ-based snow hydrologic reference simulations. To simulate the hydrological cycle, we use the physically based Cold Regions Hydrological Model (CRHM) (Pomeroy et al., 2007), which we already tested intensively with very good results in this area (Weber et al., 2016, 2020). Moreover,
CRHM was successfully applied in other snow-dominated catchments (Dornes et al., 2008; Ellis et al., 2010; Essery et al., 2009; Fang et al., 2013; López-Moreno et al., 2013). We conducted all CRHM model runs for a 10 -year period in the past (September 2000-August 2010), where all input data are available in parallel. The focus of the model output analysis is on the snow cover and runoff. The snow cover simulations are compared to measured snow depth data. We first set up a reference run with in situ-measured meteorological data and a $2.5 \mathrm{~m}$ high-resolution DEM. Then, we tested 11 setups with different meteorological driver data and three setups with different DEMs and compared them to the reference run, which allowed us to assess differences in quantity and temporal development as well as the overall applicability of the simulated snow hydrological situation regarding the different globally available products.

\section{Methods}

In the following, we first describe the study site and the model structure as well as the preparation of the forcing datasets and the DEMs used. Then we present a comparison of the forcing datasets and the influence of the DEMs on the characteristics of the hydrological response unit (HRU) parameters.

\subsection{The Research Catchment Zugspitze}

The high-alpine RCZ (centre coordinates are UTM Z: 32T, E: 653692, N: 5250416; Fig. 1) is located in the Zugspitze massif in the European Northern Calcareous Alps and covers an area of $12 \mathrm{~km}^{2}$. For the peak of the Zugspitze (2962 m a.s.1.), Germany's highest mountain, we calculated from the data recorded by the German Weather Service (DWD) an annual mean temperature of $-4.5^{\circ} \mathrm{C}(1981-2010)$ and an annual precipitation sum of $2080 \mathrm{~mm} \mathrm{a}^{-1}$ (1981-2010). Due to the geological situation and glacial processes during the Pleistocene and the Little Ice Age (1550-1850), the terrain of the RCZ is characterized by both karst and glacial features, forming a rugged surface (Hüttl, 1999; Hirtlreiter, 1992). Furthermore, the glaciers Northern Schneeferner and Southern Schneeferner are located in the catchment, covering a total area of $0.24 \mathrm{~km}^{2}$ in 2015 (Hagg, 2020). As the catchment's altitudinal relief is in total approx. $1600 \mathrm{~m}$, and the surface's heterogeneity in slope angle, aspect and curvature is highly variable, the meteorological and topographic conditions are changing over short distances. The runoff is gauged at $1365 \mathrm{~m}$ a.s.l. at the Partnach Spring and shows a clear peak in spring and summer runoff, which is characteristic for the snow-dominated runoff regime. The catchment's upper part (above $2000 \mathrm{~m}$ a.s.l.) is free of vegetation, except for sparse alpine meadows and pioneer plants, while areas below $2000 \mathrm{~m}$ a.s.l. are characterized by krummholz (Friedmann and Korch, 2010). Despite the predominant permeable karst, 


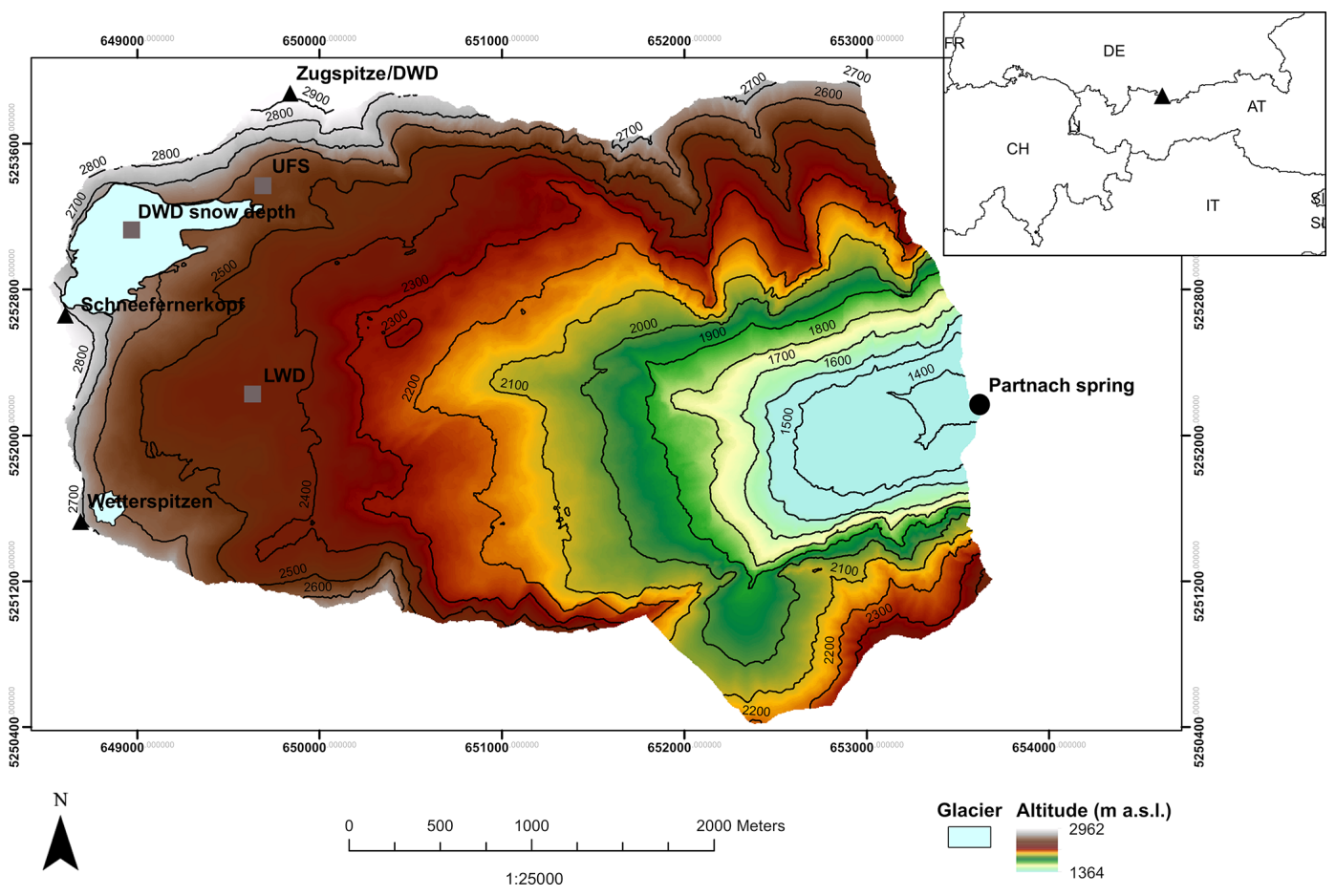

Figure 1. Overview of the Research Catchment Zugspitze (RCZ) and location of in situ stations. DWD represents German Weather Service, LWD represents Bavarian Avalanche Warning Service and UFS represents Environmental Research Station Schneefernerhaus.

Table 1. Automatic weather stations and measured parameters $\left(T_{\mathrm{a}}=\right.$ air temperature, $\mathrm{ppt}=$ precipitation, $\mathrm{RH}=$ relative humidity, $u=$ wind speed, $Q_{\mathrm{si}}=$ shortwave incoming radiation, $Q_{\mathrm{li}}=$ longwave incoming radiation and $\mathrm{SD}=$ snow depth).

\begin{tabular}{llll}
\hline Station name & Altitude (m a.s.l.) & Measured parameters & Data available since \\
\hline DWD & $2964, \mathrm{SD}$ at 2600 & $T_{\mathrm{a}}, \mathrm{ppt}, \mathrm{RH}, u, Q_{\mathrm{si}}, Q_{\mathrm{li}}$, sunshine duration, SD & 1900 (radiation data 2009) \\
LWD & 2420 & $T_{\mathrm{a}}, \mathrm{ppt}, \mathrm{RH}, u, Q_{\mathrm{si}}, \mathrm{SD}$ & 1998 \\
\hline
\end{tabular}

tracer studies have shown that the RCZ exclusively drains to the Partnach Spring (Wrobel, 1980; Rappl et al., 2010). This, in combination with the easy accessibility via ropeways and the excellent scientific infrastructure, provided by the Environmental Research Station Schneefernerhaus (UFS), makes the RCZ ideal for snow and/or hydrological research (Härer et al., 2013, 2018; Hürkamp et al., 2019; Morche and Schmidt, 2012; Weber et al., 2020). Within the catchment, we had access to data from two automatic weather stations (AWSs), providing meteorological and snow recordings for at least 20 years (Table 1). Both stations cover all meteorological parameters (Table 1) in an hourly resolution. DWD automatically records the meteorological parameters close to the summit of the Zugspitze, whereas the DWD snow depth is measured daily with a snow stake at $2600 \mathrm{~m}$ a.s.l. on the Northern Schneeferner. The second station is operated by the Bavarian Avalanche Warning Service (LWD) and is located lower at an altitude of $2420 \mathrm{~m}$ a.s.l. We use measured SWE data at the LWD station, which were available in recent years to determine an undercatch of $50 \%$ of snow pre- cipitation (Weber et al., 2020). This is well within the range of snow precipitation underestimation reported in literature (WMO, 2011; Grossi et al., 2017). Therefore, we used the factor of 1.5 to correct snow precipitation measured at the DWD station which is used for model forcing. The factor was determined using $10 \mathrm{~min}$ values to minimize the effect of sublimation from the snow cover. However, the potential effect of snow redistribution by wind on this factor could not be detected by analysing the SWE in periods with temperatures below the freezing point, strong winds and without snowfall. Besides, it has to be noted that strong winds rarely occur without precipitation in RCZ, pointing to some limitations of this factor determination for undercatch of snow. Table 1 gives an overview of the RCZ including the locations of the in situ stations and the measured parameters. For more detailed information on the physiography of the RCZ, we refer the reader to Weber et al. (2016), Friedmann and Korch (2010), Rappl et al. (2010) and Wetzel (2004). 


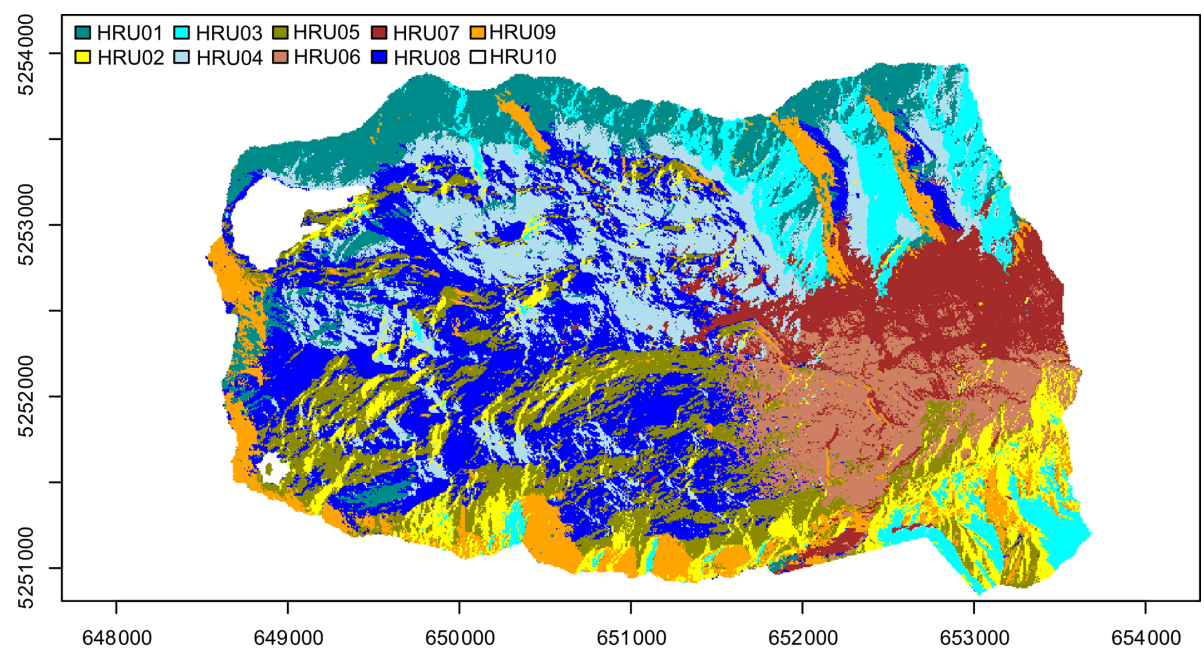

Figure 2. Hydrological response unit (HRU) discretization of the Research Catchment Zugspitze (Weber et al., 2020).

\subsection{Structure of the Cold Regions Hydrological Model}

For simulating the water cycle of the RCZ, we used CRHM, which is a physically based modelling platform which uses hydrological response units (HRUs) for spatial discretization and which was explicitly designed to simulate (snow) hydrological processes in small-to-medium-sized catchments in cold arctic and alpine environments (Pomeroy et al., 2007). Following the approach proposed by Weber et al. (2020), which is briefly explained in the following, the HRU scheme for RCZ encompasses the same HRUs also for this study (Fig. 2). Weber et al. (2020) derived HRUs via a cluster analysis of the catchment's physiographic properties: aspect, slope angle, altitude, vegetation and a wind sheltering index developed by Winstral et al. (2002). The general idea behind the concept is that spatial units that are assumed to behave hydrologically in the same way due to the natural features are assigned to one HRU. One HRU does not necessarily have to be one single area but can contain several areas with similar topographic attributes (Flügel, 1995). To define the appropriate number of clusters, i.e. the appropriate number of HRUs, the cluster analysis needs a reference for evaluation. Since the snow cover is the dominant component of the water cycle of the RCZ, Weber et al. (2020) chose the dominant pattern in the snow cover as reference. This was carried out under the assumptions that snow depth and its distribution are the dominant components in the water cycle of RCZ and that the snow depth distribution is a result of the interaction between meteorology and land surface (Dadic et al., 2010; Mott et al., 2014). To identify the dominant snow cover pattern, a time series of snow depth maps, which was derived with terrestrial laser scanning, was investigated via principal component analysis (PCA). In the following, the clustering that best reflects this PCA-derived pattern was chosen as the HRU scheme. For more information on this HRU derivation method, we refer the reader to Weber et al. (2020). The ad- vantage of this approach is that the HRUs are derived objectively and in a sufficient quantity to guarantee optimal representation of the controlling processes while at the same time ensuring computational efficiency. It turned out that 10 HRUs are optimal to represent the catchment's snow cover distribution. The areal extension, land cover and the main characteristics of the topographic parameters (altitude, slope and aspect of these 10 HRUs) are presented in Fig. 2 and for different DEM products in Table 2. The topographic characteristics for the reference setup are those of the $2.5 \mathrm{~m}$ resolution reference DEM setup.

Regarding the meteorological input, CRHM requires air temperature, relative humidity, precipitation, wind speed, and shortwave and longwave incoming radiation for each HRU. For the reference setup, these data are provided by the DWD station. CRHM has a modular structure, which allows for a model setup according to the available input data and the alignment of the research question. The model structure of CRHM is briefly depicted in Weber et al. (2016) and extensively described in Pomeroy et al. (2007). Snow melt processes are described by SnobalCRHM (Marks et al., 1999; MacDonald et al., 2010), which is an energy balance model specifically designed for deep alpine snow covers. Aspect and slope angle influence the radiation budget and thus melt processes in the catchment. Therefore, radiation parameters, like direct and diffuse radiation as well as a slope correction, are calculated in CRHM with a method created by Garnier and Ohmura (1970). This method uses the ratio of measured shortwave radiation $\left(Q_{\mathrm{si}}\right)$ and the calculated clear-sky direct and diffuse $Q_{\mathrm{si}}$ on a horizontal plane to adjust the calculated clear-sky value on the HRU-specific slope. The net radiation of the whole spectrum is calculated with an approach developed by Brunt (1932). For HRU-specific albedo calculations, CRHM uses a procedure developed by Essery and Etchevers (2004), and Pomeroy and Li (2000) created the method to calculate snow transport. Regarding evapotranspi- 


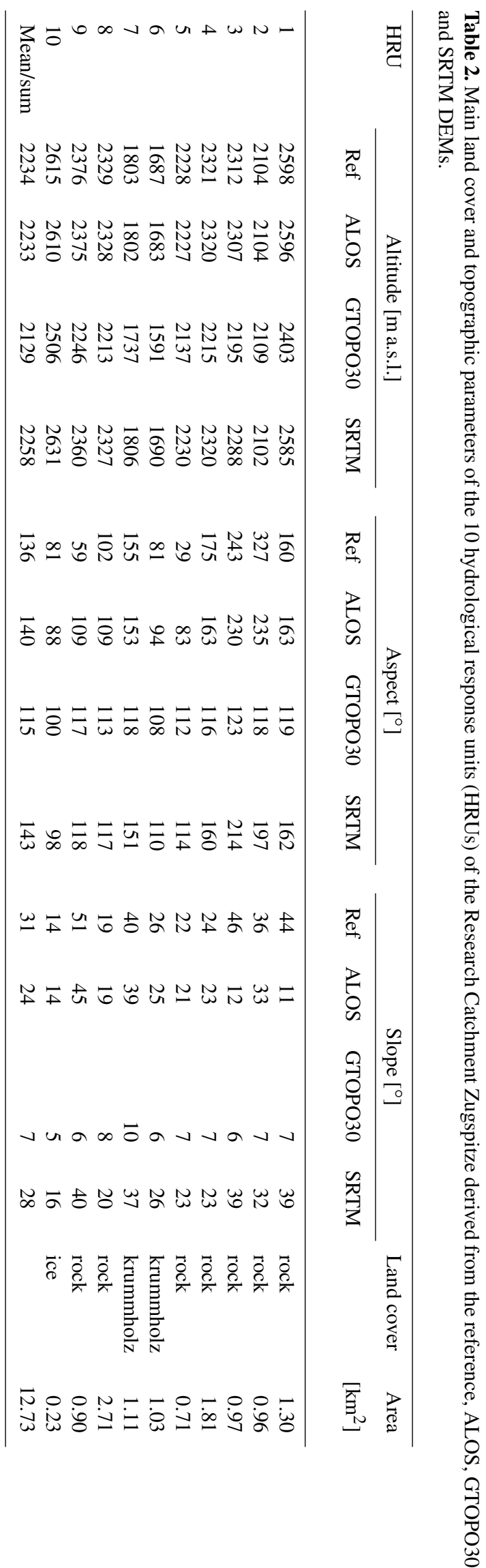

ration, CRHM uses an approach developed by Granger and Pomeroy (1997). Interception and sublimation are modelled with a procedure developed by Ellis et al. (2010). All these calculations require information on catchment topography, which is characterized by the HRUs (Table 2).

In addition to the necessary information on topography, CRHM needs information on the land cover. In general, the vegetation characteristics of the RCZ are rather simple from a snow hydrological point of view. Only the lower parts are covered with krummholz. Therefore, we do not apply specific remote sensing data or products to derive further vegetation and land cover data but stick to the good description of the land cover of the RCZ by Friedmann and Korch (2010). The extent of the glaciated areas within RCZ is derived from Hagg (2020). Unlike most hydrological models, CRHM does not require calibration. The only parameters that we adjusted for modelling are the previously named catchment or HRUspecific physiographic characteristics.

\subsection{Meteorological input data and their preparation for model input}

As meteorological input for the reference simulation, we use only the data measured at the DWD station on the Zugspitze which represents the "gauged basin mode". These data are the best in terms of continuity and data quality directly measured in RCZ. With these data, we already successfully conducted snow hydrological modelling, as shown in Weber et al. (2020). Measured snow depth could be modelled with an accuracy of NSE $>0.7$ (Nash-Sutcliffe efficiency; Nash and Sutcliffe, 1970). Due to some huge gaps in the LWD data during summer time as well as in spring, we refrained from using it as model input. We pre-processed the station measurements at DWD according to Weber et al. (2016). This includes the detection and removal of measurement errors and the interpolation of data gaps according to a procedure proposed by Liston and Elder (2006). The corrected data were then transferred to the HRUs following the method of Liston and Elder (2006) as well. This method uses monthly variable lapse rates for temperature (Kunkel, 1989) and a monthly variable precipitation adjustment factor (Thornton et al., 1997) for the altitude-dependent adjustment of temperature and precipitation. Relative humidity was adjusted via dew point temperature, which has a relatively linear dependence on elevation (Liston and Elder, 2006). The same method is also applied for the non-reference meteorological and DEM input data, which is presented in the following.

To investigate the potential performance of data not measured in situ in the RCZ, we set up the CRHM simulations also for an "ungauged basin mode", in which we assume to have no measured model forcing data, with a selection of in total 11 different meteorological setups using the following data categories: 
Table 3. Used meteorological datasets $\left(T_{\mathrm{a}}=\right.$ temperature, $\mathrm{RH}=$ relative humidity, $\mathrm{ppt}=$ precipitation, $Q_{\mathrm{si}}=$ shortwave incoming radiation, $Q_{\text {li }}=$ longwave incoming radiation, $u=$ wind speed and AWS $=$ automatic weather station).

\begin{tabular}{llllcl}
\hline Dataset & $\begin{array}{l}\text { Temporal } \\
\text { resolution }\end{array}$ & Type & Spatial resolution & $\begin{array}{c}\text { Altitude } \\
{[\mathrm{m} \text { a.s.1.] }}\end{array}$ & Parameters \\
\hline Reference & $1 \mathrm{~h}$ & AWS & point measurement & 2964 & $T_{\mathrm{a}}, \mathrm{RH}, \mathrm{ppt}, Q_{\mathrm{si}}, Q_{\mathrm{li}}, u$ \\
DWD_Wendelstein & $1 \mathrm{~h}$ & AWS & point measurement & 1832 & $T_{\mathrm{a}}, \mathrm{RH}, \mathrm{ppt}, Q_{\mathrm{si}}$, cloud cover, $u$ \\
GLDAS1 & $3 \mathrm{~h}$ & hybrid & $0.25^{\circ}$ & 1530 & $T_{\mathrm{a}}, \mathrm{RH}, \mathrm{ppt}, Q_{\mathrm{si}}, Q_{\mathrm{li}}, u$ \\
GLDAS2 & $3 \mathrm{~h}$ & hybrid & $0.25^{\circ}$ & 1530 & $T_{\mathrm{a}}, \mathrm{RH}, \mathrm{ppt}, Q_{\mathrm{si}}, Q_{\mathrm{li}}, u$ \\
GLDAS2_repro & $3 \mathrm{~h}$ & hybrid & $0.25^{\circ}$ & 1530 & $T_{\mathrm{a}}, \mathrm{RH}, \mathrm{ppt}, Q_{\mathrm{si}}, Q_{\mathrm{li}}, u$ \\
GLDAS2.1 & $3 \mathrm{~h}$ & hybrid & $0.25^{\circ}$ & 1530 & $T_{\mathrm{a}}, \mathrm{RH}, \mathrm{ppt}, Q_{\mathrm{si}}, Q_{\mathrm{li}}, u$ \\
ERA-20C & $6 \mathrm{~h}$ & hybrid & $125 \mathrm{~km}$ & 1287 & $T_{\mathrm{a}}, \mathrm{RH}, \mathrm{ppt}, Q_{\mathrm{si}}, Q_{\mathrm{li}}, u$ \\
ERA-20C_corr & $6 \mathrm{~h}$ & hybrid & $125 \mathrm{~km}$ & 1287 & $T_{\mathrm{a}}, \mathrm{RH}, \mathrm{ppt}, Q_{\mathrm{si}}, Q_{\mathrm{li}}, u$ \\
ERA5 & $1 \mathrm{~h}$ & hybrid & $31 \mathrm{~km}$ & 1427 & $T_{\mathrm{a}}, \mathrm{RH}, \mathrm{ppt}, Q_{\mathrm{si}}, Q_{\mathrm{li}}, u$ \\
ERA5-Land & $1 \mathrm{~h}$ & hybrid & $9 \mathrm{~km}$ & 1540 & $T_{\mathrm{a}}, \mathrm{RH}, \mathrm{ppt}, Q_{\mathrm{si}}, Q_{\mathrm{li}}, u$ \\
CFSR & $6 \mathrm{~h}$ & hybrid & $0.20^{\circ}$ & 1909 & $\mathrm{ppt}$ \\
CHIRPS & $1 \mathrm{~d}$ & hybrid & $0.05^{\circ}$ & & \\
\hline
\end{tabular}

- hybrid data, which are a combination of satellite products, ground-based data and atmospheric models, for all meteorological driver data;

- hybrid data using a site-specific downscaling with temperature correction;

- hybrid data for the supplementation of precipitation data only;

- data transferred from a similar catchment.

In order to guarantee comparability, we chose data that overlaps for at least 10 years which is between September 2000 and August 2010. Moreover, the same HRU delineation as for the reference was applied. For our study, we came up with the datasets listed in Table 3.

Regarding the hybrid data, we forced CRHM with the well-known Climate Forecast System Reanalysis (CFSR) dataset provided by the National Centers for Environmental Prediction (NCEP) (Saha et al., 2010). Moreover, we used NASA's Global Land Data Assimilation Systems (GLDAS) (Rodell et al., 2004), ERA-20C (Poli et al., 2016) and the new ERA5 (Hersbach et al., 2020) and ERA5-Land (Muñoz Sabater, 2019). CFSR, GLDAS, ERA-20C, ERA5 and ERA5-Land products combine in situ measurements, remote sensing and atmospheric modelling. ERA5 and ERA5Land are the latest members of the ERA family, and ERA5Land has a relatively high spatial resolution with $9 \mathrm{~km}$. We use four different versions of GLDAS to test potential differences. The differences between the GLDAS versions occur in the atmospheric models and the forcing data. Forcing data of GLDAS1 and GLDAS2.1 simulations are a combination of NCEP's Global Data Assimilation System (GDAS), disaggregated CMAP (CPC Merged Analysis of Precipitation) precipitation (Arkin et al., 2018) and Air Force Weather Agency radiation datasets (Eylander et al., 2021). GLDAS2, is forced with the Princeton Global Meteorological Forcing Dataset (Sheffield et al., 2006) and GLDAS2_repro with an updated version of it. Simulations of GLDAS1 are conducted with the Noah 2.7.1 model (Niu et al., 2011), whereas the other GLDAS simulations are conducted with the Noah 3.3 model. The reason for choosing the relatively coarse $(125 \mathrm{~km})$ ERA-20C data is that we wanted to examine the effect of the temperature correction approach by Gao et al. (2012) which was developed with ERA-20C data and in situ data from RCZ (ERA-20C_corr).

Regarding the category of hybrid products providing precipitation data only, we chose data from the Climate Hazards group Infrared Precipitation with Stations (CHIRPS) (Funk et al., 2015; Love et al., 2004), which provides daily precipitation at a spatial resolution of $0.05^{\circ}$. The idea of choosing CHIRPS data was to test the model performance in case only precipitation needs to be substituted. For the remaining meteorological driver data, we used the measured meteorological reference data. The motivation behind this specific setup was that precipitation gauges are costly to maintain and precipitation measurements in mountain environments are often highly error prone (WMO, 2011; Grossi et al., 2017; Weber et al., 2020; Germann and Joss, 2004; Hrachowitz and Weiler, 2011), whilst the other input parameters are easier to acquire and more reliable, especially in winter. Thus, there is a frequent interest and need to compensate the lack of precipitation data in high-alpine areas.

In addition to the globally and publicly available data, we transferred data from another alpine DWD station situated on the top of Wendelstein (1832 m a.s.1.) (DWD_Wendelstein) to our study catchment. This station is located approximately $84 \mathrm{~km}$ to the northeast of RCZ in the same alpine climate surrounding the northern rim of the Alps. As proposed by Liu et al. (2013) in the PUB initiative, we borrowed the recorded data for all meteorological parameters and transferred them to the RCZ. This station had the best available dataset, as 
we had no access to other alpine datasets in the vicinity at an altitude comparable to the meteorological station at the Zugspitze and for the investigated time period. As no longwave radiation was recorded at Wendelstein, we used the available cloud cover and temperature data to calculate it following a combination of the approaches from Konzelmann et al. (1994) for clear-sky conditions and König-Langlo and Augstein (1994) and Sedlar and Hock (2009) for overcast conditions. Prior to this application, we tested the procedure with measured data from the Zugspitze and could achieve good accordance with a NSE of 0.81 . Table 3 provides an overview of all meteorological input datasets used for this study. Additionally, the mean altitude of the datasets is shown - information that is needed for the transfer of each meteorological parameter to each HRU according to the method by Liston and Elder (2006), which has been described in Sect. 3.2. Regarding all the globally and publicly available data providing the meteorological input, the spatial resolution is coarser than the areal extent of the whole RCZ, which is therefore represented by only one pixel (Table 3). Thus, these data can be considered a point measurement at the given altitude. The CHIRPS data are slightly finer in their spatial resolution with four pixels covering the entire RCZ. However, the resolution is still too coarse for a precise attribution to the individual HRUs. Therefore, we took the mean of the four pixels, as the altitude differences between the four pixels are negligible, and treated it like a point measurement.

\subsection{Applied DEMs to describe the land surface parameters}

Besides the meteorological input data, land surface information, such as altitude, slope and aspect, are needed to parameterize each HRU (see Sect. 2.2). This HRU-specific information is needed by CRHM for a number of routines which calculate albedo, snow transport, the share of snow in precipitation or sublimation (see also Sect. 2.2). Due to remoteness and high costs, an individual high-resolution DEM that we used in our reference setup is not available for the majority of high-alpine catchments in the world. Thus, we aim to examine how well land surface information, derived from globally and publicly available DEMs, performs for snow hydrological CRHM simulations in the RCZ. For this purpose, we chose the ALOS (Advanced Land Observing Satellite) DEM (Tadono et al., 2014) and the SRTM (Shuttle Radar Topography Mission) DEM (Farr et al., 2007), both with a spatial resolution of $30 \mathrm{~m}$. This makes it interesting to investigate whether there are big differences despite the same spatial resolution. Moreover, we chose the GTOPO30 DEM with a spatial resolution of $30 \mathrm{arcsec}$ (approx. $600 \times 900 \mathrm{~m}$ in RCZ) (USGS, 1996; Gesch et al., 1999). The SRTM and the GTOPO30 DEMs are especially well known and have been frequently used for hydrologic modelling (Ludwig and Schneider, 2006; Nagaveni et al., 2019; Seyler et al., 2009). In 2010, the Global Multi-resolution Terrain Eleva- tion Data 2010 (GMTED2010) was published to replace GTOPO30. GMTED2010 consists of SRTM data, if available, and other DEMs with variable resolution outside the SRTM coverage (Danielson and Gesch, 2011). It is obvious that in more recent years, the DEM products with higher spatial accuracy increased in their usage compared to older and less accurate products like GTOPO30. Nevertheless, we want to examine their performance in snow hydrological modelling since it used to be a standard product for hydrological applications for many years. An additional globally and publicly available DEM with a $30 \mathrm{~m}$ resolution that was updated in 2019 would be the ASTER DEM (Abrams and Crippen, 2019).

\section{Results}

We first compared the meteorological input data as well as the influence of different global DEMs on meteorological conditions. In a second step we simulated snow depth for all setups and performed further snow hydrological investigations with the most plausible setups. The results in comparison to measured in situ data and the reference simulation are presented in the following.

\subsection{Comparison of the different meteorological input datasets}

We compared the air temperature and precipitation of all setups with the in situ-measured meteorological reference dataset. Although we consider the measured data to be the reference, it is not sure at this point of the paper that it performs best in modelling the snow cover. Therefore, the presented results are relative. Table 4 provides the 10 -year mean values of the individual datasets for the RCZ. The differences in the mean decadal annual air temperature between the warmest and coldest meteorological setup is $3.5^{\circ} \mathrm{C}$. The mean annual air temperature of the reference is $0.9^{\circ} \mathrm{C}$, which is warmer than all others. As the CHIRPS setup only supplements precipitation, temperature is identical to the reference. Reasons for the pronounced higher temperatures of the measured reference could be inversion or Föhn conditions, which are not represented properly in global products. With $-2.6^{\circ} \mathrm{C}$, the coldest dataset regarding the mean annual temperature is represented by ERA-20C. In contrast, the temperature of the ERA-20C_corr setup is closer to the reference. The newer and higher resolution ERA5 and ERA5Land setups are in a similar range with -1.8 and $-2.5^{\circ} \mathrm{C}$. The mean annual air temperature of all other driver data is between those rather cold ERA setups and the reference. Interestingly, the differences among the GLDAS versions are quite high. As Fig. 3a shows, the differences between all datasets are almost constant over the years. In addition, Fig. 3 presents a climatology information with the 30-year (19912020) median, the interquartile range (IQR), expressing a 
quantile range of $25 \%$ to $75 \%$ and the total range of the reference data. For the annual mean temperature, it is obvious that no dataset except some years of DWD_Wendelstein as well as the GLDAS2 and GLDAS2_repro is within the range that was measured at DWD during the last 30 years.

According to the reference dataset, the catchment receives a mean annual precipitation sum of $1830 \mathrm{~mm}$ in the study period. The range in the mean decadal annual precipitation sum between the wettest and driest meteorological setup is very high with $1510 \mathrm{~mm}$ (Table 4). The smallest values are 1651 (GLDAS1) and $1660 \mathrm{~mm} \mathrm{a}^{-1}$ (GLDAS2.1), being the driest setups, and the maximum value is $3161 \mathrm{~mm} \mathrm{a}^{-1}$ (CFSR), corresponding to $70 \%$ higher mean annual precipitation compared to the reference. All other datasets indicate wetter conditions than the reference. In contrast, the differences in annual precipitation show no constant offset (Fig. 3b). Although in the same climatic region, the precipitation measured at the DWD station Wendelstein shows a contrary development to the reference data between 2005 and 2010, which might be due to small-scale local effects. Only precipitation data from ERA5 and CFSR are close to the reference data over the last 30 years. An overview on the decadal mean monthly precipitation sums provides information on the annual precipitation regime of the individual setups (Fig. 4). In general, not all precipitation regimes follow the same pattern. The reference and DWD_Wendelstein datasets follow a regime with predominant precipitation during the snow accumulation period. All other meteorological datasets reach their maximum precipitation in summer but also show a local maximum in March. The CHIRPS precipitation is similar to the reference but with a more pronounced maximum in August. As we focus on the seasonal snow cover, we assume that precipitation amount and regime is of major importance for snow cover simulations.

The 10-year monthly mean of incoming shortwave radiation $\left(Q_{\mathrm{si}}\right)$ for the RCZ, relevant for snow cover depletion, is presented in Fig. 6. All setups show very similar data. However, some data, e.g. the ones of ERA5, ERA5-Land and DWD_Wendelstein, show almost a plateau from spring to summer in contrast to the reference (Fig. 6a). A possible reason might be that convective clouds form during this period while the Zugspitze is frequently above the condensation level.

To sum it up, the majority of the global products is not in the climatological range of the in situ data regarding the mean annual temperature and mean annual precipitation and indicates large offsets. This is also true for the interannual variability of monthly precipitation sums; however, they are for the most setups within the total range of the climatology. All ERA products and the CFSR datasets are significantly colder and wetter compared to the reference dataset. The DWD_Wendelstein, GLDAS2 and GLDAS2_repro datasets are slightly colder and wetter, and the GLDAS1 and GLDAS2.1 datasets are colder and drier than the reference. The CHIRPS dataset only differs in precipitation with the reference but showing a similar precipitation regime. The effects of these deviations on snowhydrological processes will be shown in Sect. 3.3 and 3.4.

\subsection{Influence of the DEMs and associated land surface parameters on meteorological conditions}

The HRU elevation, slope and aspect obtained with the $30 \mathrm{~m}$ resolution DEMs ALOS and SRTM are similar to the ones obtained with the $2.5 \mathrm{~m}$ high-resolution reference DEM (Table 2). The variance of slope and aspect angles in the coarse GTOPO30 DEM setup is very low. This means that almost all HRUs are represented quite similarly from a topographical perspective. Compared to the reference, for some HRUs parameterized with GTOPO30, the aspect is even almost $180^{\circ}$ different. The slope angles vary up to $45^{\circ}$, which does not give a realistic topographic picture of the HRUs and influences the radiation budget. To demonstrate the effect of different topographic characteristics, we used the reference meteorological dataset from DWD and adjusted it to the ALOS, SRTM, and GTOPO30 DEM-specific HRU altitude, slope, and aspect (Table 2) as explained in Sect. 2.3. Differences in the meteorological variables due to variations in topography are summarized in Fig. 3. The $0.9^{\circ} \mathrm{C}$ higher decadal mean temperature of the GTOPO30 setup when compared to the reference is caused by the $105 \mathrm{~m}$ lower catchment mean altitude (Table 2). The mean catchment altitudes of the ALOS and the SRTM setups are 2233 and $2258 \mathrm{~m}$ a.s.l., respectively, which are very close to the mean catchment altitude of the reference DEM with 2234 m a.s.l. The catchment mean temperature deviates only $0.1^{\circ} \mathrm{C}$ for the two global DEMs from the reference dataset. Since the precipitation adjustment is - like the temperature adjustment - also carried out according to an altitude-dependent principal (Sect. 2.3), the 10year mean annual precipitation sum listed in Table 4 shows a similar picture like the temperature. The GTOPO30 setup differs considerably also regarding the mean annual precipitation sum. It is $139 \mathrm{~mm}$ less than the reference caused by the lower mean catchment altitude. It is worth noticing that the initial meteorological data, and therefore the precipitation regime, is the same in each DEM setup (Fig. 4).

Pronounced differences also occur for $Q_{\text {si }}$ (Table 4), since this parameter is largely influenced by slope and aspect. Figure 5 presents the 10-year mean of $Q_{\mathrm{si}}$ in each HRU. The greatest variation in radiation can be seen in the reference setup due to the high resolution of the DEM, which represents even very small-scale topographic differences. In contrast, the lowest variation can be seen for the coarse GTOPO30 setup. For both DEMs with $30 \mathrm{~m}$ spatial resolution, variations in the ALOS setup are slightly larger compared to the SRTM setup. This is because the SRTM DEM is smoother due to a specific post-processing algorithm used for this product which becomes obvious in the steep terrain (Guth, 2006). The representation of $Q_{\text {si }}$ using the ALOS 


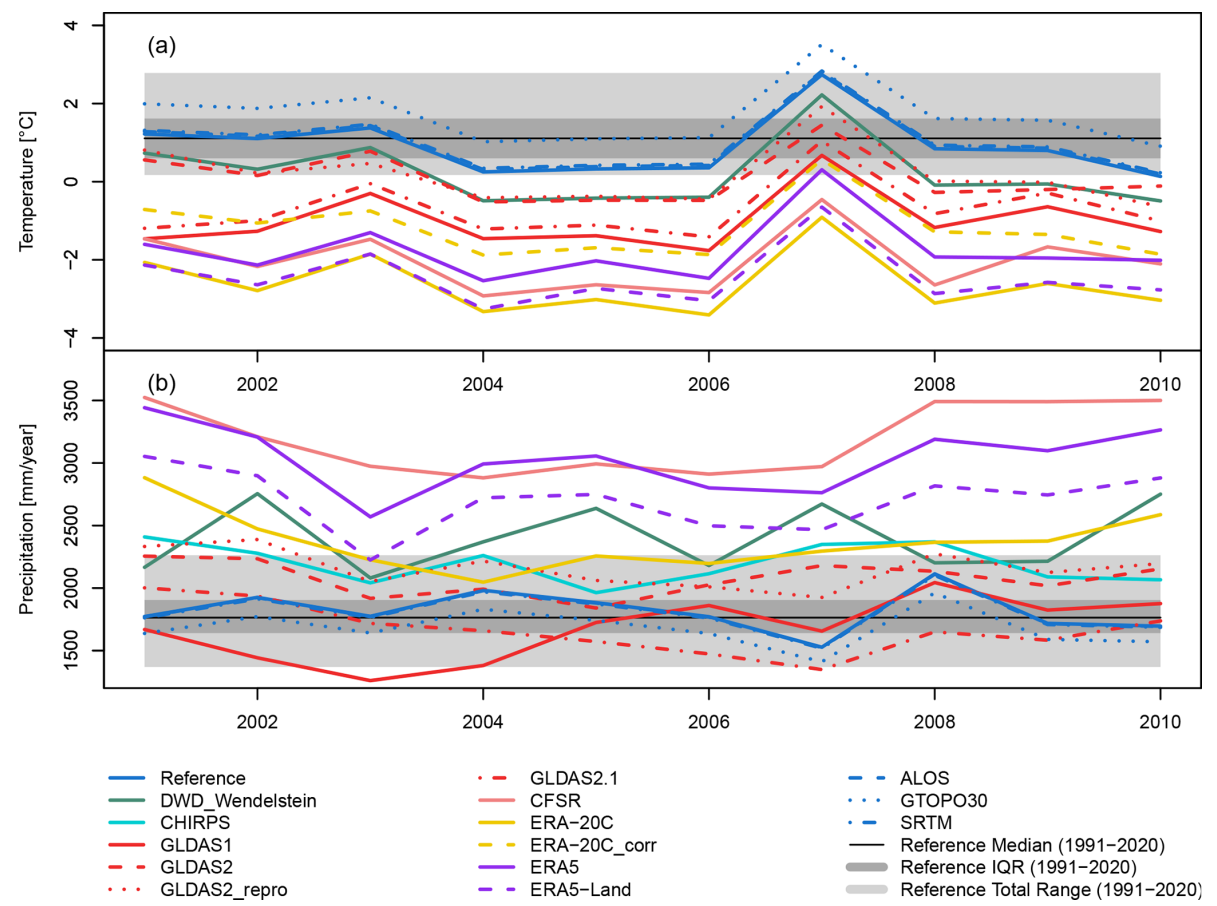

Figure 3. Annual Research Catchment Zugspitze mean of (a) air temperature and (b) precipitation sum of the different meteorological setups and of the different DEM setups.

Table 4. The 10-year Research Catchment Zugspitze mean of annual air temperature and annual precipitation sum of the input datasets. Area-weighted 10-year catchment mean of temperature, annual precipitation sum and shortwave incoming radiation $\left(Q_{\mathrm{si}}\right)$ of the reference setup and the setups global meteorological data and land surface parameterization on the basis of global DEMs.

\begin{tabular}{lrcc}
\hline Dataset & $\begin{array}{r}\text { Temperature } \\
\text { mean }\left[{ }^{\circ} \mathrm{C}\right]\end{array}$ & $\begin{array}{c}\text { Precipitation } \\
{\left[\mathrm{mm} \mathrm{a}^{-1}\right]}\end{array}$ & $\begin{array}{c}Q_{\text {si }} \\
{\left[\mathrm{W} \mathrm{m}^{-2}\right]}\end{array}$ \\
\hline Reference & 0.9 & 1830 & 139 \\
DWD_Wendelstein & 0.2 & 2364 & 133 \\
GLDAS1 & -1.0 & 1651 & 142 \\
GLDAS2 & 0.1 & 2066 & 134 \\
GLDAS2_repro & 0.2 & 2154 & 131 \\
GLDAS2.1 & -0.7 & 1660 & 131 \\
ERA-20C & -2.6 & 2347 & 151 \\
ERA-20C_corr & -1.2 & 2347 & 151 \\
ERA5 & -1.8 & 3038 & 143 \\
ERA5-Land & -2.5 & 2705 & 145 \\
CFSR & -2.0 & 3161 & 146 \\
CHIRPS & 0.9 & 2208 & 139 \\
GTOPO30 & 1.8 & 1691 & 147 \\
ALOS & 1.0 & 1814 & 124 \\
SRTM & 1.0 & 1809 & 116 \\
\hline
\end{tabular}

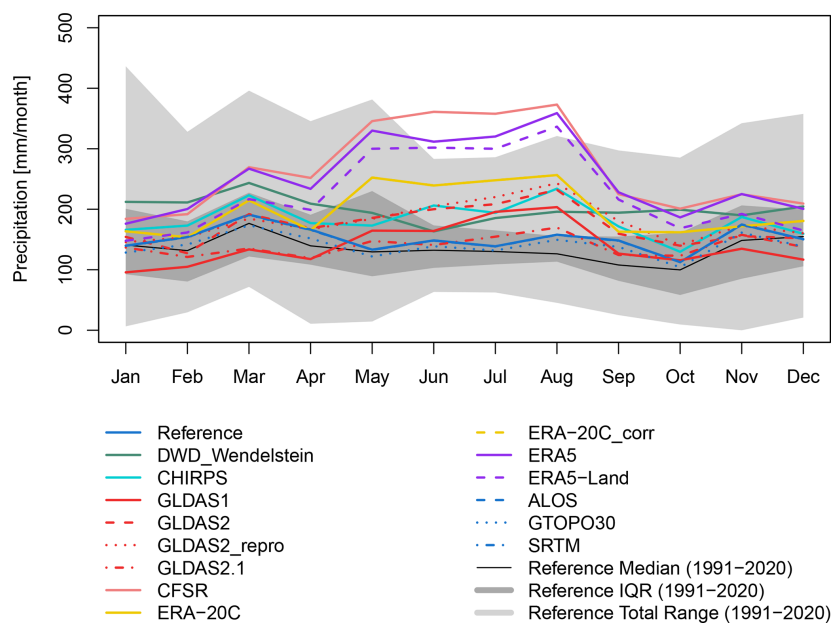

Figure 4. The 10-year average of monthly precipitation sums of the different meteorological setups and of the different DEM setups.

DEM is closer to the reference DEM. Differences between SRTM and ALOS might also occur due to different sensor viewing angles. In addition to the spatial distribution of $Q_{\mathrm{si}}$ in the catchments, Fig. $6 \mathrm{~b}$ shows the 10-year mean annual cycle of $Q_{\mathrm{si}}$ for the RCZ and illustrates the same mean annual radiation curve of the three DEM setups with an almost constant bias.

To summarize, the resolution or processing of the DEM does not only influence aspect and slope angles, and thus $Q_{\mathrm{si}}$, 

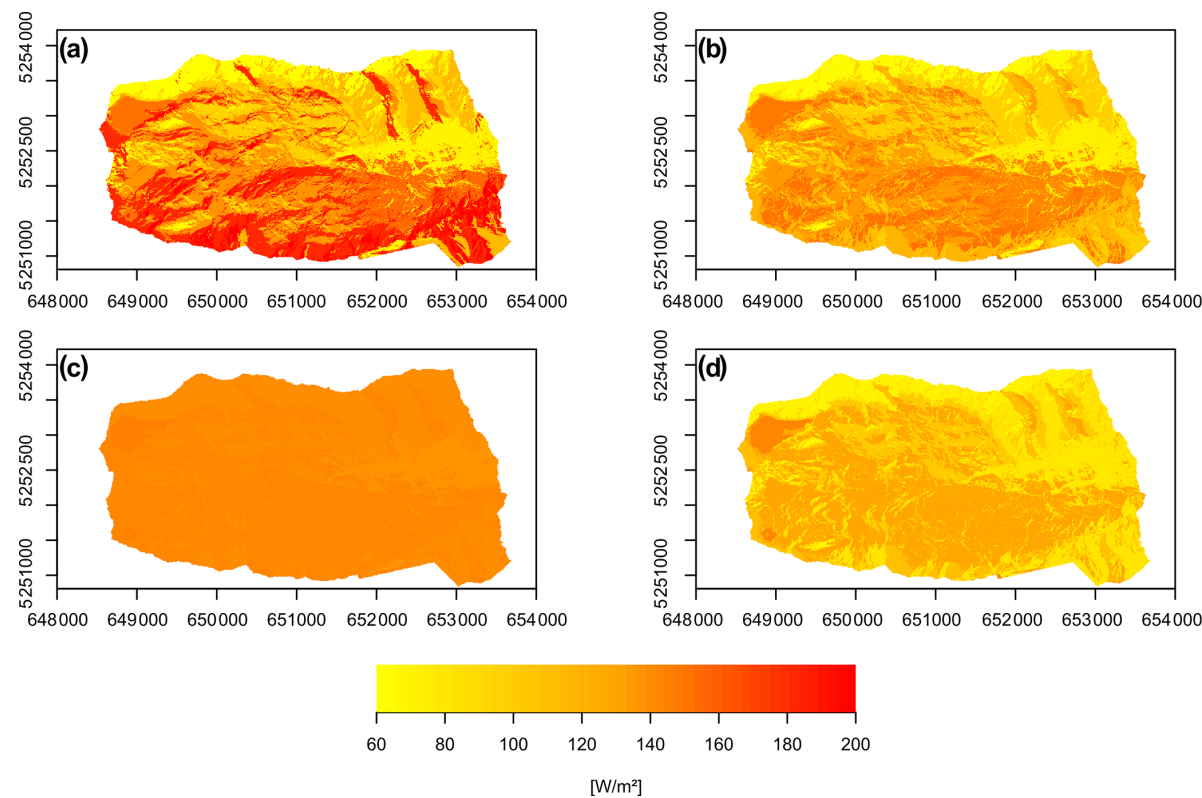

Figure 5. The 10-year mean of shortwave incoming radiation $\left(Q_{\mathrm{si}}\right)$ in the (a) reference, (b) ALOS, (c) GTOPO30 and (d) SRTM setups.

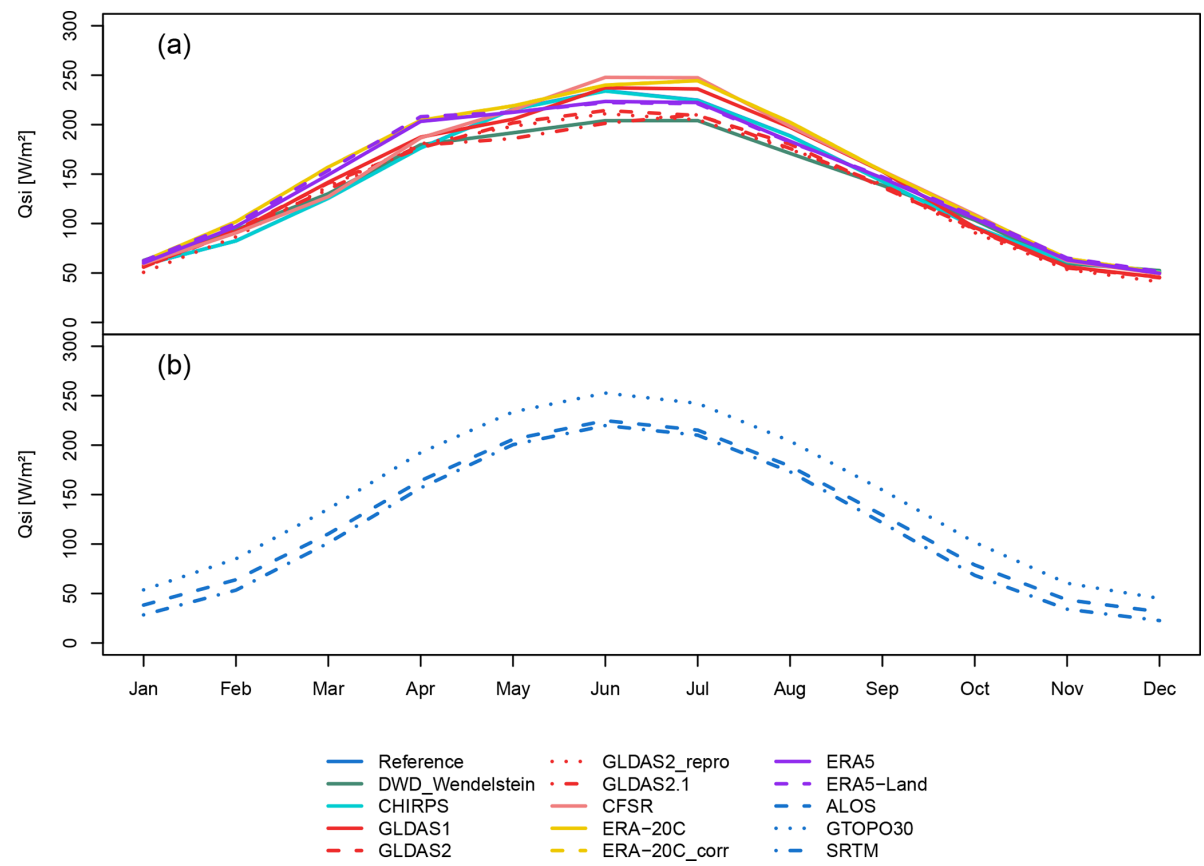

Figure 6. The 10-year mean monthly shortwave incoming radiation $\left(Q_{\text {si }}\right)$ of the Research Catchment Zugspitze of (a) the different meteorological setups and of (b) the different DEM setups.

but also elevation. As a consequence, this affects the calculation of the catchment and HRU mean temperature and precipitation values, which is especially and significantly different for the very coarse GTOPO30 DEM setup. Despite the ALOS and SRTM DEMs having the same spatial resolution, the different smoothing algorithms which have been applied to generate these products result in considerable differences in $Q_{\text {si }}$ due to differences in aspect and slope angle.

\subsection{Evaluation of simulated snow depth with measured data}

In a next step, the different meteorological and DEM setups for HRU parameterization were used as data input for snow 
Measured vs. modelled at DWD station

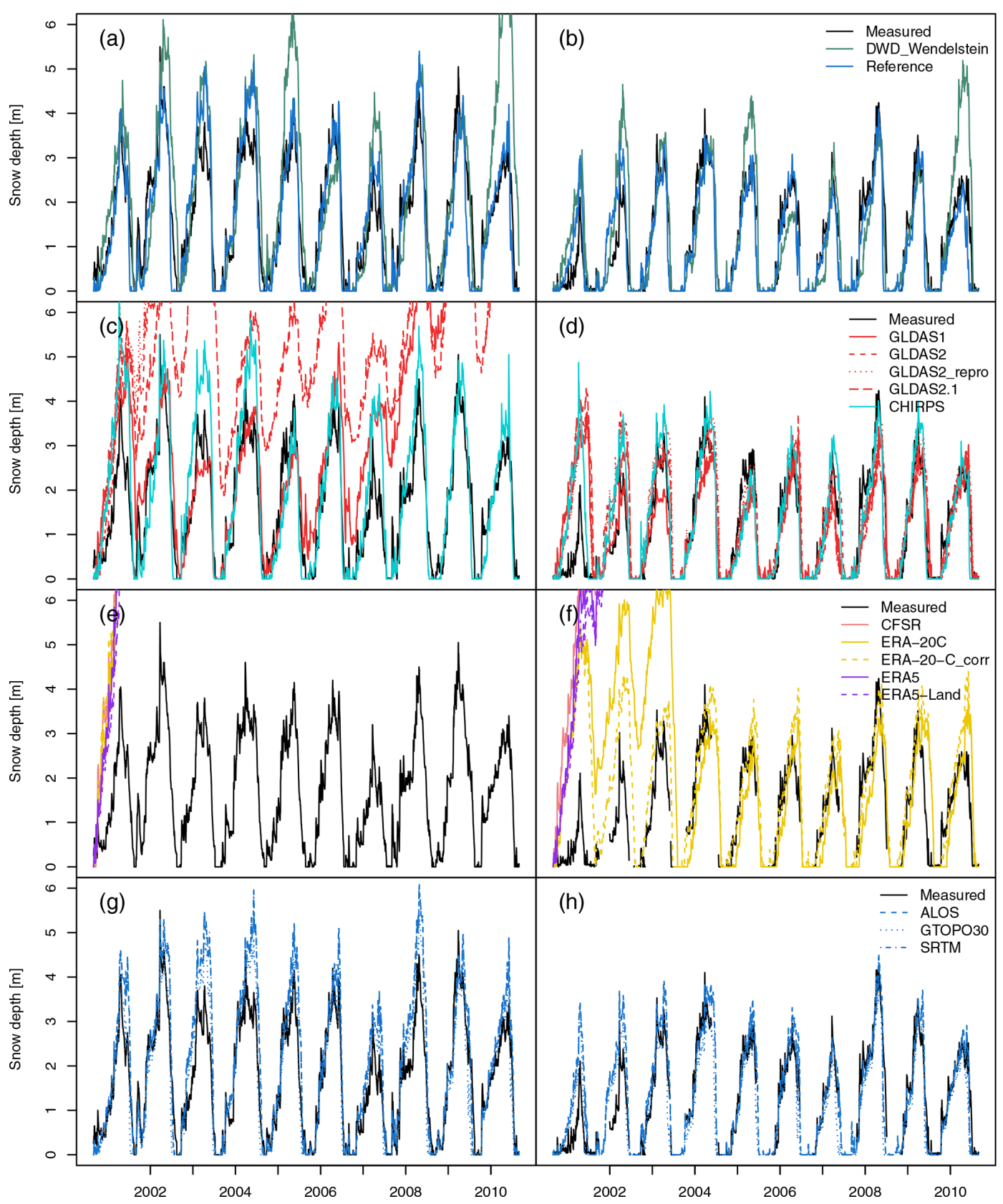

Figure 7. Comparison of modelled snow depth results with measured snow depth at the measurement sites of Bavarian Avalanche Warning Service (LWD) and German Weather Service (DWD). Panels (a) to (f) are related to different meteorological input setups and panels (g) and (h) to different hydrological response unit (HRU) parameterizations using different DEMs.

hydrological simulations with CRHM. To evaluate the quality of the simulated results of all setups including the reference, we compared at first, as presented in this section, the modelled snow depth on a daily basis with in situ measurements that are available in two HRUs. The DWD snow depth measurement site is located in HRU10 and is only $15 \mathrm{~m}$ lower than HRU altitude. The LWD station is located in HRU4 but is situated $99 \mathrm{~m}$ higher than the HRU altitude. Table 5 pro- vides the quality measures NSE, coefficient of determination $\left(R^{2}\right)$ and the mean absolute error (MAE).

Figure 7 compares the simulated daily snow depth of all different meteorological and DEM model setups including the measured snow depth at the DWD and the LWD stations. It is obvious that the simulated snow depth with the reference model setup fits best with the measured data for both stations (Fig. 7a and b). This is also reflected in the high statistical 
Table 5. Statistical overview of simulation results of snow depth by using different meteorological input data and hydrological response unit parameterizations according to different DEMs and measurements performed at the measurement sites of the German Weather Service (DWD) and the Bavarian Avalanche Warning Service (LWD). NSE = Nash-Sutcliffe efficiency, $R^{2}=$ coefficient of determination and $\mathrm{MAE}=$ mean absolute error.

\begin{tabular}{lrrrrrr}
\hline Dataset & $\begin{array}{r}\text { NSE } \\
\text { LWD }\end{array}$ & $\begin{array}{r}\text { NSE } \\
\text { DWD }\end{array}$ & $\begin{array}{c}R^{2} \\
\text { LWD }\end{array}$ & $\begin{array}{r}R^{2} \\
\text { DWD }\end{array}$ & $\begin{array}{r}\text { MAE } \\
\text { LWD } \\
{[\mathrm{m}]}\end{array}$ & $\begin{array}{r}\text { MAE } \\
\text { DWD } \\
{[\mathrm{m}]}\end{array}$ \\
\hline Reference & 0.79 & 0.79 & 0.81 & 0.86 & 0.32 & 0.41 \\
DWD_Wendelstein & 0.33 & 0.11 & 0.59 & 0.66 & 0.61 & 0.84 \\
GLDAS1 & 0.46 & -6.25 & 0.49 & 0.12 & 0.51 & 2.28 \\
GLDAS2 & 0.31 & -195.84 & 0.47 & 0.01 & 0.57 & 15.15 \\
GLDAS2_repro & 0.36 & -266.87 & 0.55 & 0.01 & 0.55 & 17.94 \\
GLDAS2.1 & 0.14 & -8.11 & 0.33 & 0.39 & 0.46 & 3.59 \\
ERA-20C & -2.57 & -743.77 & 0.09 & 0.00 & 1.41 & 30.19 \\
ERA-20C_corr & -0.55 & -690.06 & 0.37 & 0.00 & 0.84 & 29.25 \\
ERA5 & -593.07 & -1648.16 & 0.07 & 0.00 & 22.13 & 42.18 \\
ERA5-Land & -669.14 & -1138.21 & 0.07 & 0.00 & 23.35 & 36.98 \\
CFSR & -25.53 & -37.22 & 0.07 & 0.00 & 24.50 & 42.08 \\
CHIRPS & 0.55 & 0.54 & 0.66 & 0.79 & 0.49 & 0.63 \\
GTOPO30 & 0.79 & 0.84 & 0.81 & 0.89 & 0.33 & 0.37 \\
ALOS & 0.77 & 0.68 & 0.83 & 0.89 & 0.33 & 0.50 \\
SRTM & 0.79 & 0.66 & 0.83 & 0.89 & 0.31 & 0.51 \\
\hline
\end{tabular}

values regarding a NSE of $0.79, R^{2}$ values of 0.81 and 0.86 , and the lowest mean absolute error (MAE) as shown in Table 5. The results of the reference run and the majority of all setups are better for the LWD station than for the DWD station. One reason for this could be that the DWD snow depth is measured directly on top of the glacier. The ice has a cooling effect on the snow cover which leads to a delayed melt out of a thin snow cover compared to a faster melt of snow directly on top of rocks. This effect is particularly strong in spring and autumn, and it is not considered in the model. However, this effect is negligible in the case where larger amounts of snow are piled up on top of the glacier, as it is the case for most of the time during the winter season. Thus, modelled snow cover at the DWD station lasts on average $20 \mathrm{~d}$ less than the measured one.

The comparison of the snow depth results simulated by all setups with different meteorological input data, including the reference with the measurements at the two stations, can be summarized as follows: the simulations, using the transferred data from the DWD AWS at Wendelstein (Fig. 7a and b) and the CHIRPS dataset (Fig. 7c and d), both produce plausible results at each measurement station (Table 5). The NSE values of the CHIRPS setup range between 0.54 and 0.55 ; the $R^{2}$ values range between 0.66 and 0.79 (Table 5). The reason for the good performance of the CHIRPS setup is that the forcing data are the same as in the reference setup except from precipitation. The overestimation of snow depth in some years, especially at the DWD site, is due to the higher precipitation values as described in Sect. 3.1. For the snow depth simulations based on the transferred data from the alpine DWD AWS at Wendel- stein, we also obtained reasonable but weaker results, e.g. with an $R^{2}$ of 0.59 and 0.66 at LWD and DWD, respectively, but higher MAE values. The NSE values at the stations are 0.33 and 0.11 , respectively. The statistical values are rather moderate but still hint at a plausible representation of the temporal development compared to the results of the other global data. The low NSE values can be traced back to the years 2002, 2005 and 2010 in which the peaks are strongly overestimated in the DWD_Wendelstein run at both stations. Both the CHIRPS and DWD_Wendelstein data show temperature and precipitation data which are for most years within the total range of climatology. All four GLDAS setups (Fig. 7d) and the ERA-20_corr (Fig. 7f) setup, except for the years 2001 to 2003 that indicate too high snow depths, reflect quite well the quantity and the temporal dynamics of the snow cover development at the LWD station. However, this is not the case for the simulations at the DWD station (Fig. 7c and e), where so-called "snow towers" pile up resulting in very low $R^{2}$ and NSE values as well as high MAEs (Table 5). Snow towers are an effect in snow hydrological modelling that occurs mainly at higher altitudes and describes the unrealistically high accumulation of snow over several years. Reasons can be the insufficient description of redistribution processes in the model or unrealistic meteorological forcing data (Freudiger et al., 2017) as the latter will be true in our case. These simulated snow towers are caused by much lower temperatures and much higher precipitation compared to the reference (Sect. 3.1). The same can be observed for the CFSR, ERA5 and ERA5-Land setups, even at both measurement stations. The relatively better performance of the ERA-20C_cor setup compared to the ERA-20C setup 
originates from the local temperature downscaling which has already been tested for the high-alpine Zugspitze by Gao et al. (2012). Moreover, the previously described effect of snow towers also occurred in the two highest located HRUs for all GLDAS and ERA-20C_corr setups and also at further HRUs within the catchment for GLDAS2, GLDAS2.1, GLDAS2_repro and the ERA-20C datasets. The location of the highest HRU can be one reason for the lower accordance of snow depth at the DWD station compared to the LWD station regarding the simulated results of all global meteorological setups. This favours temperatures and precipitation amounts, which can lead to the development of snow towers.

Regarding the snow depth results simulated by using the model setups with different topographic characteristics on the basis of the $2.5 \mathrm{~m}$ DEM for the reference run and the three different globally and publicly available DEMs ALOS, SRTM and GTOPO30, the snow depth development was simulated realistically at both measurement sites (Fig. $7 \mathrm{~g}$ and h, Table 5). This results in $R^{2}$ values above 0.8, NSE values above 0.77 and MAE values below 0.33 for all three global data setups at the LWD site being close to the statistical values of the reference. For GTOPO30, the quality measures for the DWD site are even slightly better, whereas the ALOS and SRTM setups show slightly weaker NSE, $R^{2}$ and MAE values at the DWD site (Table 5). The two $30 \mathrm{~m}$ DEMs SRTM and ALOS show slight differences in the NSE values at the measurement stations, which can be attributed to differences in the sensing angles and post-processing algorithms leading to topographic differences and as a consequence also to differences especially in $Q_{\text {si }}$ as mentioned in Sect. 3.2.

In summary, besides the simulation of snow depth with the reference setup, only the setups with the transferred dataset from the DWD station at Wendelstein as well as the simulations with precipitation substituted by CHIRPS gave plausible results for the two measurement stations and showed no snow towers in any HRU. However, the validity of the simulated snow depth is largely limited by using all other global products, which means that for these products the substitution of all meteorological parameters using atmospheric model, hybrid or reanalysis data as model input for snow depth simulations is unfortunately not useful. Although it was possible to simulate plausible snow depth for some years and for some HRUs, e.g. at the LWD station, with the GLDAS setups as well as with ERA-20C and ERA20C_corr, they are also classified as non-reliable, as in several HRUs simulated snow towers piled up. In contrast to the global meteorological setups, the simulations of snow depth with all different DEM setups produced reasonable results.

\subsection{Comparison of snow hydrologically relevant indices and the simulated runoff regime}

In the following, we present the effect of different meteorological and DEM model input datasets on specific snow hydrological indices calculated for the entire RCZ and single
HRUs as well as the catchment mean runoff. As the majority of products was already classified as unreliable in Sect. 3.3, we only chose the model runs that produced plausible snow depth results within all HRUs of the RCZ for the investigation in this section (Table 6). This encompasses, besides the reference setup, the DWD_Wendelstein and CHIRPS setups as well as all DEM setups.

As specific snow hydrological indices, we chose the maximum snow water equivalent (MSWE), the day of MSWE (DMSWE), the snow cover duration and the number of ablation days. The last index is defined as the days between the DMSWE and the last day with snow cover. Since no SWE measurements are available in the investigated time period, we compare the simulation results to the results obtained with the reference setup. We refrained from evaluating the snow cover duration and the number of ablation days with measured snow depth data for two reasons. First, these values cannot be determined in most years at the LWD station, because of data gaps in snow depth measurements due to lightning strikes, which occur mainly in spring and autumn. Second, as already mentioned, the DWD snow depth measurements which are performed directly on the glacier surface might bias the parameters on snow cover duration and ablation periods due to a delayed melt out. As with SWE, we do not compare the simulated runoff with measured data. One reason for this is the existence of large gaps in the measured runoff data (months to years). Another reason is the generally poor data quality of measured runoff during the analysed period, which is due to maintenance issues in this harsh high-alpine environment.

For the catchment mean and varying meteorological products, Table 6 shows an overestimation of MSWE in the CHIRPS and DWD_Wendelstein setup of $15 \%$ and $20 \%$, respectively, compared to the reference setup. This overestimation is related to the 378 and $534 \mathrm{~mm}$ higher mean annual precipitation sum in the CHIRPS and the DWD_Wendelstein setups. For the DWD_Wendelstein setup, the combination with the lower mean temperature leads to a $12 \mathrm{~d}$ later occurrence of the DMSWE, a $22 \mathrm{~d}$ longer snow cover duration and a 2-week longer ablation period on average for the entire catchment. In contrast, the later DMSWE, the longer snow cover duration and the longer melting period of the CHIRPS setup is solely due to higher winter precipitation and the resulting higher MSWE. As a consequence, the higher MSWE values in these two meteorologically different setups result in a higher runoff of $29 \%$ and $30 \%$, respectively (Table 6). The runoff regimes of both setups show considerable differences compared to the reference with its peak in June as presented in Fig. 8. The peak runoff of the CHIRPS setup occurs in June and July, whilst the peak runoff of the DWD_Wendelstein setup is in total 1 month later, which is due to lower spring temperatures that lead to a slower ablation and the longer availability of snow for melting in summer. 
Table 6. Catchment 10-year means of maximum snow water equivalent (MSWE), day of the year of maximum snow water equivalent (DMSWE), snow cover duration, ablation days and runoff in the Research Catchment Zugspitze.

\begin{tabular}{lrcccc}
\hline Dataset & MSWE [mm] & $\begin{array}{c}\text { DMSWE } \\
{[\text { DoY }]}\end{array}$ & $\begin{array}{c}\text { Snow } \\
\text { cover } \\
\text { duration } \\
{[\mathrm{d}]}\end{array}$ & $\begin{array}{c}\text { Ablation } \\
\text { days }\end{array}$ & $\begin{array}{c}\text { Runoff } \\
{\left[\mathrm{m}^{3} \mathrm{~s}^{-1}\right]}\end{array}$ \\
\hline Reference & 854 & 108 & 223 & 40 & 0.69 \\
DWD_Wendelstein & $1028(+20 \%)$ & 120 & 255 & 54 & 0.90 \\
CHIRPS & $984(+15 \%)$ & 113 & 239 & 52 & 0.89 \\
GTOPO30 & $849(-1 \%)$ & 111 & 226 & 42 & 0.67 \\
ALOS & $1007(+18 \%)$ & 119 & 247 & 50 & 0.74 \\
SRTM & $999(+17 \%)$ & 120 & 248 & 51 & 0.74 \\
\hline
\end{tabular}

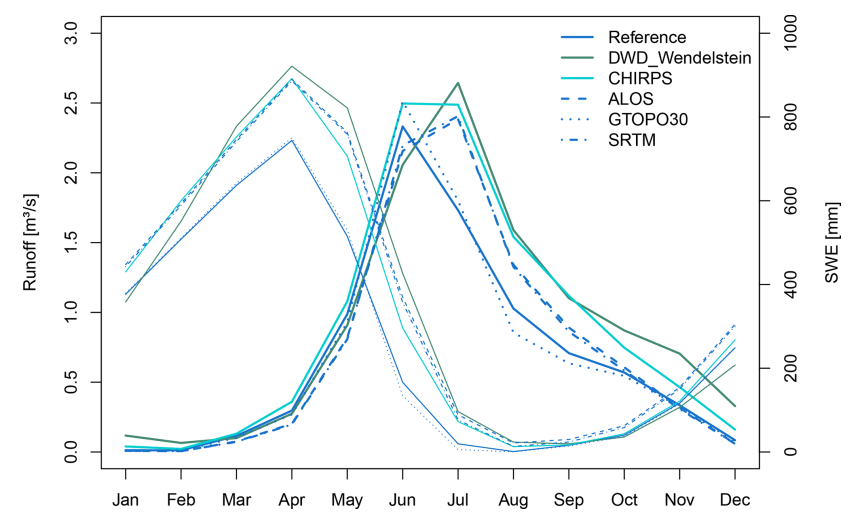

Figure 8. The 10-year mean monthly catchment runoff (bold lines refer to the left axis) and snow water equivalent (SWE; thin lines refer to the right axis) of the Research Catchment Zugspitze for the five most plausible model setups in comparison to the reference simulations.

Regarding the simulated snow hydrological results using the setups with different DEMs, the mean catchment MSWE corresponding to the GTOPO30 DEM is closest to the reference with a negligible deviation of $1 \%$ (Table 6). This good performance goes in line with the comparison of the measured and modelled snow depth data in Sect. 3.3 (Table 5). Both $30 \mathrm{~m}$ resolution DEMs result in a considerably higher catchment mean MSWE than the reference setup at $+18 \%$ in the ALOS setup and $+17 \%$ in the SRTM setup. The GTOPO30 setup shows for the DMSWE and the length of the snow cover as well as the ablation periods also the smallest deviations compared to the reference setup. The mean catchment DMSWE of the ALOS and SRTM setups occur 11 and $12 \mathrm{~d}$ later, respectively, when compared with the reference setup. Moreover, the snow cover duration in these setups is almost 1 month longer, which is reflected in their higher number of ablation days, too. This is due to considerably less received $Q_{\mathrm{si}}$ in the ALOS and SRTM setups.

The variations in the modelled snowpack development are also evident in the runoff regime (Fig. 8). The higher MSWE and its delayed occurrence in the ALOS and SRTM setups (Table 6) lead to a shift in peak runoff from June to July compared to the reference. This is favoured by snow that is still available for melt in the radiation-intense summer months. The fact that the snow cover indices of the GTOPO30 setup are so close to the reference entails a very similar runoff behaviour, despite it having the largest warm bias, precipitation underestimation and insolation overestimation (Table 4). To explain this, the differences in the process of discharge formation have to be examined. Although the GTOPO30 DEM is lower in altitude than the reference DEM, it is still high enough that monthly mean temperature is below freezing until March and only at $0.1^{\circ} \mathrm{C}$ for April, while it is at $-0.7^{\circ} \mathrm{C}$ in April in the reference. Both the reference and GTOPO30 setups are clearly above freezing with 4.2 and $5.1{ }^{\circ} \mathrm{C}$, respectively, in May. The main melt, which is temperature-induced in spring, starts almost at the same time in both setups, which is illustrated by the SWE decline in Fig. 8. Melt-induced runoff starts slightly earlier in the reference setup (Fig. 8), because there are HRUs which receive considerably more $Q_{\mathrm{si}}$ compared to the GTOPO30 setup (Fig. 4). Nonetheless, the major part of the RCZ receives more $Q_{\mathrm{si}}$ in the GTOPO30 setup. The longer the days last in spring, the stronger the radiation-induced melt effect is, which is why, in the results of the GTOPO30 setup, melt-induced runoff becomes stronger in June compared to the reference setup. In summer the lower elevation has a greater effect on the temperature compared to winter, which leads to higher melt-induced runoff in the GTOPO30 setup in June and July. This is illustrated in the faster decline of SWE in June and July in Fig. 8. This effect decreases in August since less snow is left to melt. The higher peak runoff induced by the CHIRPS setup is due to a higher snow mass availability for melt in general. The lower temperatures of the DWD_Wendelstein setup along with lower radiation in the ablation period (Fig. 6) leads to a lower runoff in June, although more snow for melt is available. The peak runoff subsequently occurs in July, when temperatures are higher. Both the CHIRPS and DWD_Wendelstein summer runoff peaks are increased by 
the higher amount of precipitation compared to the reference (Fig. 3).

In addition to the results shown for the catchment's average, Fig. 9 presents the 10-year mean MSWE, DMSWE, snow cover duration and ablation periods for each single HRU, sorted according to their mean altitude (see Table 2). It is obvious that overall all four snow hydrological parameters increase with altitude in every setup, indicating that altitude is the dominant factor for snow cover development. Most considerable differences for all setups can be observed especially for MSWE. In the CHIRPS and DWD_Wendelstein setups, the differences can mainly be explained with temperature and precipitation differences, as temperature changes are mainly linear with altitude. Differences amongst the DEMbased setups mainly occur due to different $Q_{\text {si }}$ values, which are in turn dependent on slope, aspect and altitude. As previously mentioned, the GTOPO30 causes quite homogeneous HRU conditions. The same is true, with only slight losses in variability, for the DEM setups ALOS and SRTM. Nonetheless, the two $30 \mathrm{~m}$ resolution setups show considerable differences in aspect and slope compared to the reference originating from the lower resolution. Compared to the reference, the simulated snow hydrological parameters of all tested setups indicate higher values. Although the GTOPO30 results of the catchment's average is quite similar to the reference setup, this picture is not true regarding the individual HRUs. The differences in all snow hydrological parameters between the GTOPO30 and all other setups, which are particularly noticeable in HRU1 for MSWE, can mainly be attributed to the coarse spatial resolution resulting in an almost $200 \mathrm{~m}$ lower mean altitude of HRU1 (see Table 2). Regarding the ablation period, HRU1, HRU6 and HRU10 show considerable differences between the reference and the GTOPO30 setup despite their very similar catchment mean values (see Table 6). The other seven HRUs covering $80 \%$ of RCZ are very similar to the results of the other setups, which indicates that this effect is averaged out when calculating catchment means. It could be argued that the evaluation of the simulation results on an HRU basis is insufficient due to the large heterogeneity of the catchment. However, the chosen HRU delineation partly accounts for this heterogeneity since it directly relies on the lidar-measured dominant snow depth distribution (Weber et al., 2020). Moreover, dominant snow depth patterns in high-alpine regions are largely persistent over the years as, for example, Grünewald et al. (2013) show for various highalpine catchments. We are thereafter confident that the spatial distribution of the snow cover is quite well simulated.

In summary, although the five investigated setups, including the DWD_Wendelstein and CHIRPS meteorological setups and all three global DEM setups, represented the snow depth quite well (Sect. 3.3), at a closer look considerable differences in MSWE, DMSWE, and the entire snow-covered period and the ablation periods were found compared to the reference. In addition, compared to the reference and the GTOPO30 setup, all other DEM setups indicate a higher mean monthly SWE. The differences in the snow cover results also in obvious differences in the runoff regime.

\section{Discussion on potential applications in ungauged basins}

In the following, we discuss the potential applicability of global products for snow hydrological modelling in highalpine regions as exemplarily demonstrated for the RCZ in this study. In this regard, we focus on our two initial research questions on the reliability of globally available meteorological data products and on the influence of different globally available DEM products in such complex topography. In addition we discuss potential future developments.

\subsection{Application of global meteorological data}

Garen (2013) as well as Kundzewicz and Stakhiv (2010) state that the usage of remote sensing and atmospheric modelling data is not yet common or not even applicable in hydrological modelling of mountain regions of high spatial variability and steep topographies. Due to the rather low spatial resolution of these data products, their representation of atmospheric parameters is often too coarse to describe the complex highalpine situation. In this study, we confirm this statement for all investigated globally and publicly available meteorological datasets, from which we used all necessary meteorological parameters as forcing data. According to the knowledge of the authors, studies comparing different global meteorological input data explicitly for high-alpine regions are very sparse and not available in the extent of this study. Therefore, a framework-based comparison of different studies in this regard is not possible at the current stage. In the following, however, we discuss further studies which point to a certain extent in this direction.

The replacement of precipitation only by using the CHIRPS dataset produced valid model results for snow cover and runoff for the RCZ. This quite good performance of the CHIRPS dataset was also found by Satgé et al. (2019), who used it for hydrological modelling of the Lake Titicaca region. In general, the literature findings according to the overall quality of model results using hybrid meteorological input data are not uniform. However, it seems that better results can be achieved for study sites which are located in flatter terrain or which cover only a small proportion of alpine or high-alpine areas. In contrast to our study results, for example, Fuka et al. (2013) came to the conclusion that meteorological reanalysis data perform at least as well as measured data at the catchment scale and sometimes even outperform in situ point measurements. Their test sites include a mountain watershed twice as large as RCZ, and they also tested the CFSR data. Fuka et al. (2013) explain the good model performance with CFSR's ability to represent the average catchment meteorology well in contrast to point measure- 


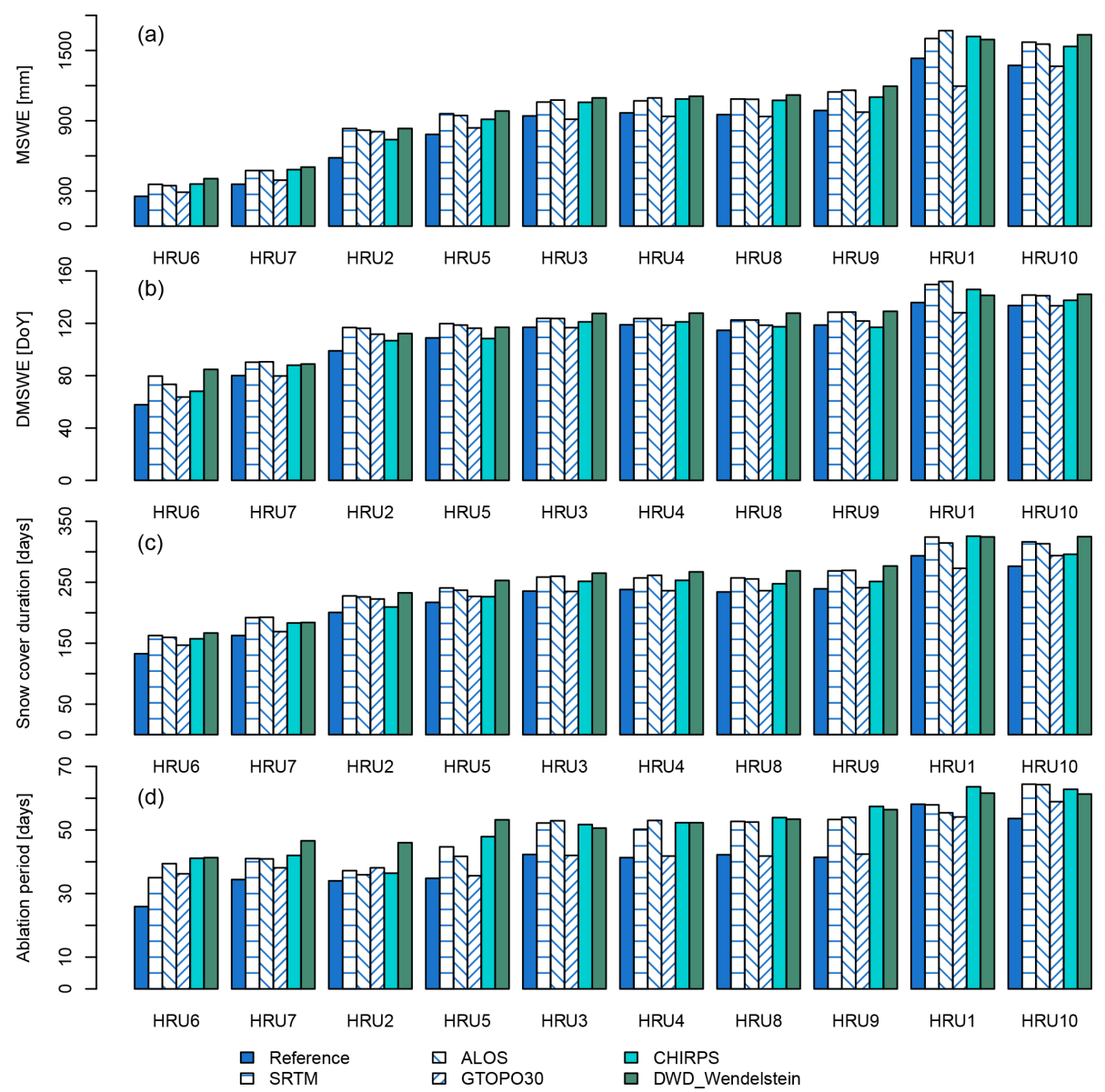

Figure 9. The 10-year mean (a) maximum snow water equivalent (MSWE), (b) day of maximum snow water equivalent (DMSWE), (c) snow cover duration, and (d) ablation period simulated for individual hydrological response units (HRUs) within the Research Catchment Zugspitze for the five most plausible model setups in comparison to the reference simulations. The HRUs are sorted from the lowest to the highest altitude (see Table 2).

ments. Thus, the weak performance we obtained with CFSR does not confirm their findings. In a study by Förster et al. (2016) focusing on the Gepatsch catchment in the central European Alps, good results in hydrological modelling could be achieved with Climate Forecast System Version 2 (CFSV2) driver data, which represent a further development of CFSR (Saha et al., 2014). However, they modelled on a monthly basis and used in situ measurements to downscale CFSV2 data in advance - a step which cannot be done for an ungauged basin. Essou et al. (2016) also demonstrates a good performance of reanalysis data as hydrological model drivers including the CFSR and ERA-Interim. Although their study includes mountainous watersheds, the watersheds are much larger than the RCZ and do not include a high-alpine headwater catchment. Therefore, their findings cannot be compared one by one to our high-alpine case. In a follow up study including the same watersheds, Essou et al. (2017) propose to use reanalysis data in combination with observation data for regional hydrological modelling to increase performance particularly in snow-dominated catchments. Casson et al. (2018) found that the application of reanalysis data in modelling SWE of subarctic catchments is problematic but can be improved by integrating observed SWE data. In contrast to our study, they used a conceptual model to simulate snow cover development, which could also lead to differences in results compared to the physically based CRHM we used.

The applied temperature correction scheme from Gao et al. (2012) for ERA-20C increased the performance of this hybrid dataset. This is a strong indication that local downscaling of meteorological data in complex terrain is very valuable. Similar conclusions on such corrections are drawn by Buytaert et al. (2010), Teutschbein et al. (2011) and Hay and Clark (2003). Thus, we would recommend applying the scheme to other global data, too.

Regarding the quite new and higher-resolved ERA5 and ERA5-Land data, we were quite surprised that both datasets are not able to better capture the meteorological situation in the RCZ. In particular from the $9 \mathrm{~km}$ resolution ERA5-Land data, we expected better results. One reason for the bad per- 
formance is the direct vicinity of the RCZ to the surrounding much lower forelands. Therefore, even ERA5-Land might be too coarse to capture this situation. The comparably low pixel altitude of this product also supports this assumption. We assume that ERA5 and ERA5-Land could be applied with much more success in a central alpine catchment where the investigated catchment is surrounded by high-alpine regions, which might be more representative for the landscape domain. This aspect could also be a reason for the bad performance of the other global data products in RCZ. As already mentioned in Sect. 3.1, another reason could be that inversion or Föhn conditions are insufficiently represented in global products in contrast to in situ-measured data.

Besides the good results with the hybrid CHIRPS precipitation product, we also achieved plausible model results for the dataset DWD_Wendelstein, by "borrowing" meteorological driver data from another alpine AWS, as suggested by the PUB initiative (Liu et al., 2013). Regarding our results for different meteorological setups, we can conclude that meteorological data transferred from stations in the closer vicinity in the same mountain range and with similar climatology still provide the best results, when all meteorological input data have to be substituted. According to Girons Lopez et al. (2020), who investigated the effect of different model structure choices of the HBV model (Bergstrom, 1995) in several catchments in mountainous areas in central Europe, there may be pronounced differences in the model response on structure changes depending on the catchment. In this context, a potential limitation of our study is that only one high-alpine catchment has been tested for all the global meteorological products, but so far we had no access to similar data for other high-alpine catchments.

\subsection{Application of global DEM products}

To the authors' knowledge, a comprehensive comparison of different globally available DEM products for various highalpine sites with very complex topography is not yet available. However, several studies which were carried out in regions other than explicitly high-alpine regions with either global or commercial products report that the spatial resolution of DEMs considerably affects the output of hydrological models. The reason is the influence of DEM resolution on the calculation of topographic parameters or indices (Sørensen and Seibert, 2007; Vaze et al., 2010; Nagaveni et al., 2019). In general, the coarser the DEM, the larger the uncertainty of the simulations. In addition, Hopkinson et al. (2010) exemplarily investigated a glaciated area and described that the DEM resolution has also a direct impact on spatio-temporal variation in simulated melt due to the scale-dependent representation of the topographic characteristics. In our study we can confirm that the simulated SWE and runoff generation is affected by the DEM resolution. However, at a first glance it seems that no matter which DEM resolution between $2.5 \mathrm{~m}$ and up to $1 \mathrm{~km}$ is used, the modelled results for the snow cover remain plausible to a certain extent. This is especially true for the two snow depth measurement sites LWD and DWD in the upper parts of the RCZ. As the GTOPO30 DEM is approx. 300 times coarser than the reference and 25 times coarser in resolution than ALOS and SRTM, this is particularly remarkable. However, on closer inspection, the GTOPO30 setup is not able to describe the topographic conditions for the individual HRUs as shown in Table 2. Slope angles are far too low and the aspect is up to $180^{\circ}$ different, which results in large $Q_{\mathrm{si}}$ offsets compared to the reference. However, the almost $100 \mathrm{~m}$ lower DEM-dependent average catchment altitude of GTOPO30 plays a minor role, since it is still high enough and temperatures are low enough that the snow cover can develop in the model as it was measured. Regarding the catchment scale, the differences among HRUs are averaged out. The GTOPO30 DEM was not created for applications in small basins with highly heterogeneous terrain and we generally would refrain from using it for such applications. Further investigations on the usage of coarser DEMs would be necessary for applications where they are required since large mountain domains should be modelled, and computational power is limited. In contrast, the two $30 \mathrm{~m}$ resolution DEMs, ALOS and SRTM, are well applicable, and we assume that they can be also applied with good success in other high-alpine regions. However, although some DEMs have the same spatial resolution, like ALOS and SRTM, they still might perform differently. One reason can be due to different techniques of DEM creation using stereo satellite imagery, interferometry or altimetry. Further differences can be due to different satellite viewing angles as well as postprocessing techniques.

\subsection{General remarks and potential future developments}

The presented results show that the right choice of the meteorological forcing data is still the biggest challenge for snow hydrological modelling in ungauged alpine headwater catchments. The choice of the DEM has far less impact on the snow cover modelling but can still result in considerable differences in snow cover as well as runoff generation. In particular for global meteorological products, a sound quality assessment of the results is inevitable, when the model is forced with meteorological data that are not measured in situ. However, our comfortable situation of having in situ data for evaluation is not the case in most high-alpine catchments. In this regard, further tests with a broad range of different global datasets in the globally and widely distributed alpine catchments of the International Network for Alpine Research Catchment Hydrology (INARCH) (http://words. usask.ca/inarch, last access: 4 January 2019), a GEWEX (Global Energy and Water Exchanges) project, would be a very helpful and logical next step. This would enable the creation of a framework of how to use globally available data for model forcing in ungauged high-alpine basins. Regarding 
globally available meteorological setups, a framework categorization could include statements on catchment size and homogeneity, climatological variability as well as its topographic characteristics. Regarding the usage of global DEM products, an investigation especially on the degree of topographic complexity and especially the steepness of terrain would be most interesting.

In the next decades, model inputs could be improved by high-resolution remote sensing products for measuring snow cover properties like snow cover extent, snow depth or even SWE. This includes using unmanned aerial vehicles (Bühler et al., 2015), satellite-based altimetry (Kwok and Markus, 2018), aerial lidar (Broxton et al., 2019) and optical tri-stereoscopic remote sensing (Shaw et al., 2020) for snow depth measurements, high-resolution synthetic aperture radar sensors for SWE derivation (Lievens et al., 2019), and satellite-based optical sensors (Notarnicola, 2020; Marti et al., 2016), or webcam data (Härer et al., 2016) for spatially and temporally improved snow cover detection. This could enhance the evaluation or initialization of snow hydrological models. Although the new Sentinel satellite series has a high temporal resolution of up to $2.5 \mathrm{~d}$, the "realistic" temporal resolution especially for optical sensors can be far less due to cloud cover issues. Another point of improvement can be seen for the meteorological reanalysis and land data assimilation methods, as they are also constantly evolved (Hersbach et al., 2019). Products such as SNODAS (Barrett, 2003) and products based on it (Lv et al., 2019) indicate a good way forward in this direction, including ground observations, satellite data and snow hydrological models, which are driven by globally available data to close the temporal and spatial gap between remotely sensed and ground-based snow cover data. Another step in this direction is the direct usage of snow cover data from reanalysis products like ERA5 or ERA5Land (Hersbach et al., 2020) that might provide information for model evaluation or initialization purposes. However, their current spatial resolutions of 31 and $9 \mathrm{~km}$, respectively, are most probably too coarse for heterogeneous high-alpine terrain as also seen in this study regarding the meteorological data. However, we assume further spatial refinement of such products in the coming years. As with the global meteorological products, we also expect a constant improvement in spatial resolution for DEMs. Considering all these developments, we see great potential that snow cover products with high spatial and temporal resolution could be available with large improvements for many alpine headwater catchments in the future.

\section{Conclusions}

In this study, we evaluated the applicability of global data products regarding their application for snow hydrological modelling in a high-alpine region for potential use in ungauged basins. For the snow hydrological simulations, we set up the physically based CRHM in the high-alpine RCZ of $12 \mathrm{~km}^{2}$ in the European Northern Calcareous Alps for a study period of 10 years (September 2000-August 2010). In the RCZ, we were able to evaluate "ungauged basin" mode simulations with measured in situ data and reference simulations. We compared snow depth as well as snow hydrological parameters like MSWE, DMSWE, snow cover duration, ablation period and runoff. To answer our first research question on the potential applicability of globally available meteorological data, we examined data from CFSR, different versions of GLDAS, CHIRPS, ERA5, ERA5-Land and ERA20C including a specific downscaling approach, as well as a data transfer from another alpine station. All meteorological input data as well as the simulated snow hydrological results of the in total 11 different meteorological setups were compared to a reference relying on in situ-measured data. To answer our second research question on the influence of different global DEM products on snow hydrological modelling in complex terrain, we tested the impact of the GTOPO30 (approx. $1 \mathrm{~km}$ ) as well as ALOS and SRTM DEMs (both $30 \mathrm{~m}$ ). We compared these results to results produced by a setup using a $2.5 \mathrm{~m}$ high-resolution reference DEM.

Regarding all 11 meteorological setups we tested in comparison to the reference, we could only obtain plausible results for two setups for the catchment mean as well as for all HRUs. This is true for the snow depth development which was compared to measurements at two sites and for other snow hydrological indices and the catchment's runoff. Those two plausible setups are the CHIRPS setup in which precipitation only is substituted whilst taking all other meteorological data from the reference in situ dataset, and the meteorological dataset which was borrowed from another alpine AWS in the catchment's greater vicinity at Wendelstein. In contrast, all other meteorological setups which are globally and publicly available datasets substituting all meteorological variables produced a totally unrealistic snow cover development for at least some parts of the catchment. This is especially true for the upper measurement station and the upper HRUs. To some extent, with the setups based on ERA20C reanalysis data and different versions of GLDAS, we could simulate the snow cover development at one measurement site quite reasonably. The application of temperature downscaling improved the quality of the ERA-20C setup. The CFSR data as well as ERA5 and ERA5-Land setups performed worst and produced so-called snow towers in all parts of the catchment due to too low temperatures, leading to the fact that the snowpack could not melt completely, even in summer.

The simulated results performed with the three setups, relying on different topographic characteristics based on the different globally available DEMs, performed overall quite well in comparison to the references - even though they differ widely in their spatial resolution. As a consequence of their different spatial resolutions, product origin and product post-processing, variations in altitude, slope and aspect 
especially influence the radiation balance but also temperature and precipitation calculated for each HRU. Although the coarsest DEM performed considerably well, this is due to the wrong reasons as small-scale topographic effects were neglected. Despite the overall good performance of the three globally available DEM setups compared to all global meteorological setups, they also showed some considerable differences in MSWE, DMSWE, snow cover duration and ablation period at the catchment scale and for individual HRUs. This results in a shift in peak runoff of up to 1 month in some setups. Based on our results, the answer to our first research question is that it is not possible to exclusively use the tested global meteorological data products to reliably simulate snow depth and further snow hydrological parameters as well as runoff in the high-alpine RCZ. One reason is that, up to now, these global products are not able to describe either the meteorological heterogeneity of such complex catchments with steep terrain or its average conditions. This is reflected in a range of $3.5^{\circ} \mathrm{C}$ in the catchment mean decadal temperature and $1510 \mathrm{~mm}$ in the catchment mean decadal annual precipitation sum over all input data for the RCZ. However, we assume that results could be different if the investigated catchment was not a topographic outlier in the landscape region as is the case with RCZ with its adjacent lower forelands.

The answer to our second question is that, compared to the influence of the different meteorological forcings on simulated snow hydrological parameters, the influence due to different characteristics of topographic parameters like slope, aspect and altitude due to different DEM products is smaller, even in complex terrain. Nonetheless, there are considerable differences mainly due to DEM product-dependent variations in the radiation balance and due to mean HRU altitudeinduced variations in temperature and precipitation. Despite the weak performance of the global meteorological products, we assume that they might produce better results if the analysed catchment is more representative of the surrounding larger-scale landscape region. Furthermore, we expect a growing importance of such data in future snow hydrological modelling, also in ungauged basins, due to their constant and rapid evolution, including temporal and spatial refinements. In order to generalize the findings from our study and to intensively test newly developed meteorological and snow hydrological products, we suggest to conduct further investigations in the well-monitored catchments from INARCH.

Data availability. All global meteorological model input data as well as the global DEM data used for HRU parameterization are publicly available as described in Sect. 2. The URLs are given here:

- GLDAS: https://ldas.gsfc.nasa.gov/gldas (last access: 4 January 2019) (Rodell et al., 2004);

- ERA-20C: https://apps.ecmwf.int/datasets (last access: 4 January 2019) (Poli et al., 2016);
- ERA5 and ERA5-Land: https://cds.climate.copernicus.eu (last access: 12 December 2020) (Hersbach et al., 2020; Muñoz Sabater, 2019);

- CHIRPS: https://www.chc.ucsb.edu/data/chirps (last access: 4 January 2019) (Funk et al., 2015);

- CFSR: https://cfs.ncep.noaa.gov (last access: 17 September 2019) (Saha et al., 2010);

- ALOS: https://www.eorc.jaxa.jp/ALOS/en/aw3d30/index.htm (last access: 21 October 2018) (Tadono et al., 2014);

- GTOPO30 and SRTM: https://www.usgs.gov/centers/eros/ science (last access: 28 December 2018) (Farr et al., 2007; Gesch et al., 1999).

The meteorological and snow depth station data from the German Weather Service (DWD) are also publicly available at https: //www.dwd.de (last access: 28 December 2018) (DWD, 2018). A second set of snow depth station data used for validation was provided by the Bavarian Avalanche Service (LWD) and can be made available upon request and approval by the LWD. The used reference DEM was provided by David Morche (Martin Luther University Halle-Wittenberg) and might also be made available upon request and upon approval by the copyright owner.

Author contributions. MW and MB conceptualized the study. MW was responsible for the methodology, carried out the investigations and the formal analysis, and wrote the original draft. FK reviewed and edited the article, acquired funds for publication and supervised the work. KS reviewed and edited the article and supervised the work.

Competing interests. The authors declare that they have no conflict of interest.

Acknowledgements. The authors want to thank David Morche (Martin-Luther-University Halle-Wittenberg) for providing the high-resolution DEM of the RCZ. We gratefully obtained meteorological and snow height station data from the Bavarian Avalanche Service (LWD) and the Umweltforschungsstation Schneefernerhaus.

Financial support. Open-access funding was provided by BOKU Vienna Open Access Publishing Fund.

Review statement. This paper was edited by Jan Seibert and reviewed by three anonymous referees. 


\section{References}

Abimbola, O. P., Wenninger, J., Venneker, R., and Mittelstet, A. R.: The assessment of water resources in ungauged catchments in Rwanda, J. Hydrol.: Reg. Stud., 13, 274-289, https://doi.org/10.1016/j.ejrh.2017.09.001, 2017.

Abrams, M. and Crippen, R.: ASTER GDEM V3 (Aster Global DEM): User Guide, available at: https://lpdaac.usgs.gov/ documents/434/ASTGTM_User_Guide_V3.pdf (last access: 25 March 2021), 2019.

Adams, M. S., Bühler, Y., and Fromm, R.: Multitemporal Accuracy and Precision Assessment of Unmanned Aerial System Photogrammetry for Slope-Scale Snow Depth Maps in Alpine Terrain, Pure Appl. Geophys., 175, 3303-3324, https://doi.org/10.1007/s00024-017-1748-y, 2018.

Arkin, P., Xie, P., and National Center for Atmospheric Research Staff: The Climate Data Guide: CMAP: CPC Merged Analysis of Precipitation, available at: https://climatedataguide.ucar.edu/ climate-data/cmap-cpc-merged-analysis-precipitation, last access: 24 December 2018.

Bandyopadhyay, J., Rodda, J. C., Kattelmann, R., Kundzewicz, Z., and Kraemer, D.: Highland waters - a resource of global significance, in: Mountains of the World. A global priority, edited by: Messerli, B. and Ives, J. D., Parthenon Publishing, New York, Carnforth, 131-155, https://doi.org/10.1002/(SICI)1099145X(200003/04)11:2<197::AID-LDR390>3.0.CO;2-U, 1997.

Barnett, T. P., Adam, J. C., and Lettenmaier, D. P.: Potential impacts of a warming climate on water availability in snow-dominated regions, Nature, 438, 303-309, https://doi.org/10.1038/nature04141, 2005.

Barrett, A. P.: National Operational Hydrologic Remote Sensing Center SNOw Data Assimilation System (SNODAS) Products at NSIDC: Special Report, NSIDC, Boulder, Colorado, 2003.

Beniston, M.: Is snow in the Alps receding or disappearing?, Wiley Interdisciplin. Rev.: Clim. Change, 3, 349-358, https://doi.org/10.1002/wcc.179, 2012.

Bergstrom, S.: The HBV model (Chapter 13, pp. 443-476), in: Computer models of watershed hydrology, edited by: Singh, V. P., Water Resources Publications, Highlands Ranch, Colorado, USA, 1130 pp., 1995.

Bernhardt, M., Härer, S., Feigl, M., and Schulz, K.: Der Wert Alpiner Forschungseinzugsgebiete im Bereich der Fernerkundung, der Schneedeckenmodellierung und der lokalen Klimamodellierung, Österreichische Wasser- und Abfallwirtschaft, 70, 515-528, https://doi.org/10.1007/s00506-018-0510-8, 2018.

Blöschl, G., Sivapalan, M., Wagener, T., Viglione, A., and Savenije, H. (Eds.): Runoff Predictions in Ungauged Basins: A Synthesis across Processes, Places and Scales, Cambridge University Press, Cambridge, https://doi.org/10.1017/CBO9781139235761, 2013.

Bormann, K. J., Brown, R. D., Derksen, C., and Painter, T. H.: Estimating snow-cover trends from space, Nat. Clim. Change, 8 , 924-928, https://doi.org/10.1038/s41558-018-0318-3, 2018.

Brown, P. D. and Mote, P. W.: The Response of Northern Hemisphere Snow Cover to a Changing Climate, J. Climate, 2008, 2124-2145, https://doi.org/10.1175/2008JCLI2665.1, 2008.

Broxton, P. D., Leeuwen, W. J. D., and Biederman, J. A.: Improving Snow Water Equivalent Maps With Machine Learning of Snow Survey and Lidar Measurements, Water Resour. Res., 73, 37393757, https://doi.org/10.1029/2018WR024146, 2019.
Brunt, D.: Notes on radiation in the atmosphere. I, Q. J. Roy. Meteorol. Soc., 58, 389-420, https://doi.org/10.1002/qj.49705824704, 1932.

Bühler, Y., Marty, M., Egli, L., Veitinger, J., Jonas, T., Thee, P., and Ginzler, C.: Snow depth mapping in high-alpine catchments using digital photogrammetry, The Cryosphere, 9, 229243, https://doi.org/10.5194/tc-9-229-2015, 2015.

Buytaert, W., Vuille, M., Dewulf, A., Urrutia, R., Karmalkar, A., and Célleri, R.: Uncertainties in climate change projections and regional downscaling in the tropical Andes: implications for water resources management, Hydrol. Earth Syst. Sci., 14, 12471258, https://doi.org/10.5194/hess-14-1247-2010, 2010.

Casson, D. R., Werner, M., Weerts, A., and Solomatine, D.: Global re-analysis datasets to improve hydrological assessment and snow water equivalent estimation in a subArctic watershed, Hydrol. Earth Syst. Sci., 22, 4685-4697, https://doi.org/10.5194/hess-22-4685-2018, 2018.

Christensen, J. H., Boberg, F., Christensen, O. B., and LucasPicher, P.: On the need for bias correction of regional climate change projections of temperature and precipitation, Geophys. Res. Lett., 35, L20709, https://doi.org/10.1029/2008GL035694, 2008.

Currier, W. R., Pflug, J., Mazzotti, G., Jonas, T., Deems, J. S., Bormann, K. J., Painter, T. H., Hiemstra, C. A., Gelvin, A., Uhlmann, Z., Spaete, L., Glenn, N. F., and Lundquist, J. D.: Comparing Aerial Lidar Observations With Terrestrial Lidar and Snow-Probe Transects From NASA's 2017 SnowEx Campaign, Water Resour. Res., 55, 6285-6294, https://doi.org/10.1029/2018WR024533, 2019.

Dadic, R., Mott, R., Lehning, M., and Burlando, P.: Wind influence on snow depth distribution and accumulation over glaciers, Environ. Res. Lett., 115, 1064, https://doi.org/10.1029/2009JF001261, 2010.

Danielson, J. J. and Gesch, D. B.: Global Multi-resolution Terrain Elevation Data 2010 (GMTED2010), available at: https: //pubs.usgs.gov/of/2011/1073/pdf/of2011-1073.pdf (last access: 24 May 2021), 2011.

Dornes, P. F., Pomeroy, J. W., Pietroniro, A., Carey, S. K., and Quinton, W. L.: Influence of landscape aggregation in modelling snow-cover ablation and snowmelt runoff in a subarctic mountainous environment, Hydrolog. Sci. J., 53, 725-740, https://doi.org/10.1623/hysj.53.4.725, 2008.

Dussaillant, J. A., Buytaert, W., Meier, C., and Espinoza, F.: Hydrological regime of remote catchments with extreme gradients under accelerated change: the Baker basin in Patagonia, Hydrolog. Sci. J., 57, 1530-1542, https://doi.org/10.1080/02626667.2012.726993, 2012.

DWD - Deutscher Wetterdienst: Wetter und Klima im Überblick, available at: https://www.dwd.de, last access: 28 December 2018 .

Ellis, C. R., Pomeroy, J. W., Brown, T., and MacDonald, J.: Simulations of snow accumulation and melt in needleleaf forest environments, Hydrol. Earth Syst. Sci., 14, 925-940, https://doi.org/10.5194/hess-14-925-2010, 2010.

Essery, R. and Etchevers, P.: Parameter sensitivity in simulations of snowmelt, J. Geophys. Res., 109, D20111, https://doi.org/10.1029/2004JD005036, 2004.

Essery, R., Rutter, N., Pomeroy, J. W., Baxter, R., Stähli, M., Gustafsson, D., Barr, A., Bartlett, P., and Elder, 
K.: SNOWMIP2: An Evaluation of Forest Snow Process Simulations, B. Am. Meteorol. Soc., 90, 1120-1135, https://doi.org/10.1175/2009BAMS2629.1, 2009.

Essou, G. R., Brissette, F., and Lucas-Picher, P.: Impacts of combining reanalyses and weather station data on the accuracy of discharge modelling, J. Hydrol., 545, 120-131, https://doi.org/10.1016/j.jhydrol.2016.12.021, 2017.

Essou, G. R. C., Sabarly, F., Lucas-Picher, P., Brissette, F., and Poulin, A.: Can Precipitation and Temperature from Meteorological Reanalyses Be Used for Hydrological Modeling?, J. Hydrometeorol., 17, 1929-1950, https://doi.org/10.1175/JHM-D15-0138.1, 2016.

Eylander, J. B., Peter-Lidard, C. D., and Kumar, S. V.: The AFWA Next Generation Land Data Assimilation System, available at: http://www.nrlmry.navy.mil/BACIMO/2005/Proceedings/ 5NWP/5.02NWPEylanderLandSurfaceAssimilationPaper.pdf, last access: 24 May 2021.

Fang, X., Pomeroy, J. W., Ellis, C. R., MacDonald, M. K., DeBeer, C. M., and Brown, T.: Multi-variable evaluation of hydrological model predictions for a headwater basin in the Canadian Rocky Mountains, Hydrol. Earth Syst. Sci., 17, 1635-1659, https://doi.org/10.5194/hess-17-1635-2013, 2013.

Farr, T. G., Rosen, P. A., Caro, E., Crippen, R., Duren, R., Hensley, S., Kobrick, M., Paller, M., Rodriguez, E., Roth, L., Seal, D., Shaffer, S., Shimada, J., Umland, J., Werner, M., Oskin, M., Burbank, D., and Alsdorf, D.: The Shuttle Radar Topography Mission, Rev. Geophys., 45, 1485, https://doi.org/10.1029/2005RG000183, 2007.

Fatichi, S., Vivoni, E. R., Ogden, F. L., Ivanov, V. Y., Mirus, B., Gochis, D., Downer, C. W., Camporese, M., Davison, J. H., Ebel, B., Jones, N., Kim, J., Mascaro, G., Niswonger, R., Restrepo, P., Rigon, R., Shen, C., Sulis, M., and Tarboton, D.: An overview of current applications, challenges, and future trends in distributed process-based models in hydrology, J. Hydrol., 537, 45-60, https://doi.org/10.1016/j.jhydrol.2016.03.026, 2016.

Fekete, B. M., Robarts, R. D., Kumagai, M., Nachtnebel, H.-P., Odada, E., and Zhulidov, A V.: Time for in situ renaissance, Science, 349, 685-686, https://doi.org/10.1126/science.aac7358, 2015.

Feki, H., Slimani, M., and Cudennec, C.: Geostatistically based optimization of a rainfall monitoring network extension: case of the climatically heterogeneous Tunisia, Hydrol. Res., 48, 514-541, https://doi.org/10.2166/nh.2016.256, 2017.

Flügel, W.: Delineating hydrological response units by geographical information system analyses for regional hydrological modelling using PRMS/MMS in the drainage basin of the River Bröl, Germany, Hydrol. Process., 1995, 423-436, 1995.

Förster, K., Oesterle, F., Hanzer, F., Schöber, J., Huttenlau, M., and Strasser, U.: A snow and ice melt seasonal prediction modelling system for Alpine reservoirs, Proc. Int. Assoc. Hydrol. Sci., 374, 143-150, https://doi.org/10.5194/piahs-374-143-2016, 2016.

Freudiger, D., Kohn, I., Seibert, J., Stahl, K., and Weiler, M.: Snow redistribution for the hydrological modeling of alpine catchments, Wires Water, 4, e1232, https://doi.org/10.1002/wat2.1232, 2017.

Friedmann, A. and Korch, O.: Die Vegetation des Zugspitzplatts (Wettersteingebirge, Bayerische Alpen): Aktueller Zustand und Dynamik, Berichte der Reinhold-Tüxen-Gesellschaft, 22, 114$128,2010$.
Fuka, D. R., Walter, M. T., MacAlister, C., Degaetano, A. T., Steenhuis, T. S., and Easton, Z. M.: Using the Climate Forecast System Reanalysis as weather input data for watershed models, Hydrol. Process., 28, 5613-5623, https://doi.org/10.1002/hyp.10073, 2013.

Funk, C., Peterson, P., Landsfeld, M., Pedreros, D., Verdin, J., Shukla, S., Husak, G., Rowland, J., Harrison, L., Hoell, A., and Michaelsen, J.: The climate hazards infrared precipitation with stations - a new environmental record for monitoring extremes, Scient. Data, 2, 150066, https://doi.org/10.1038/sdata.2015.66, 2015.

Gampe, D., Schmid, J., and Ludwig, R.: Impact of Reference Dataset Selection on RCM Evaluation, Bias Correction, and Resulting Climate Change Signals of Precipitation, J. Hydrometeorol., 20, 1813-1828, https://doi.org/10.1175/JHM-D-18-0108.1, 2019.

Gao, L., Bernhardt, M., and Schulz, K.: Downscaling ERA-Interim temperature data in comlex terrain, Hydrol. Earth Syst. Sci., 16, 4661-4673, https://doi.org/10.5194/hess-16-4661-2012, 2012.

Garen, D. C.: Choosing and Assimilation Forcing Data for Hydrological Prediction, in: Putting Prediction in Ungauged Basins into Practice, edited by: Pomeroy, J. W., Whitfield, P. H., and Spence, C., Canadian Water Resources Association, ISBN 9781-896513-38-6, 2013.

Garnier, B. J. and Ohmura, A.: The evaluation of surface variations in solar radiation income, Sol. Energy, 13, 21-34, https://doi.org/10.1016/0038-092X(70)90004-6, 1970.

Gascoin, S., Grizonnet, M., Bouchet, M., Salgues, G., and Hagolle, O.: Theia Snow collection: high-resolution operational snow cover maps from Sentinel-2 and Landsat-8 data, Earth Syst. Sci. Data, 11, 493-514, https://doi.org/10.5194/essd-11-493-2019, 2019.

Germann, U. and Joss, J.: Operational Measurement of Precipitation in Mountainous Terrain, in: Weather Radar, edited by: Meischner, P., Springer, Berlin, Heidelberg, 52-77, 2004.

Gesch, D. B., Verdin, K. L., and Greenlee, S. K.: New land surface digital elevation model covers the Earth, Eos Trans. Am. Geophys. Union, 80, 69-70, https://doi.org/10.1029/99EO00050, 1999.

Girons Lopez, M., Vis, M. J. P., Jenicek, M., Griessinger, N., and Seibert, J.: Complexity and performance of temperaturebased snow routines for runoff modelling in mountainous areas in Central Europe, Hydrol. Earth Syst. Sci. [preprint], https://doi.org/10.5194/hess-2020-57, 2020.

Granger, R. J. and Pomeroy, J. W.: Sustainability of the western Canadian boreal forest under changing hydrological conditions. I. Snow accumulation and ablation, Sustainability of Water Resources under Increasing Uncertainty, in: IAHS Publ No. 240, edited by: Rosjberg, D., Boutayeb, N., Gustard, A., Kundzewicz, Z., and Rasmussen, P., IAHS Press, Wallingford, 243-250, 1997.

Grossi, G., Lendvai, A., Peretti, G., and Ranzi, R.: Snow Precipitation Measured by Gauges: Systematic Error Estimation and Data Series Correction in the Central Italian Alps, Water, 9, 461, https://doi.org/10.3390/w9070461, 2017.

Grünewald, T., Stötter, J., Pomeroy, J. W., Dadic, R., Moreno Baños, I., Marturià, J., Spross, M., Hopkinson, C., Burlando, P., and Lehning, M.: Statistical modelling of the snow depth distribution in open alpine terrain, Hydrol. Earth Syst. Sci., 17, 3005-3021, https://doi.org/10.5194/hess-17-3005-2013, 2013. 
Guth, P. L.: Geomorphometry from SRTM, Photogram. Eng. Remote Sens., 72, 269-277, https://doi.org/10.14358/PERS.72.3.269, 2006.

Haberkorn, A.: European Snow Booklet - an Inventory of Snow Measurements in Europe, EnviDat, https://doi.org/10.16904/ENVIDAT.59, 2019.

Hagg, W.: Bayerische Gletscher, available at: http://www. bayerische-gletscher.de/ (last access: 24 May 2021), 2020.

Hall, D. K., Riggs, G. A., Salomonson, V. V., DiGirolamo, N. E., and Bayr, K. J.: MODIS snow-cover products, Remote Sens. Environ., 83, 181-194, https://doi.org/10.1016/S00344257(02)00095-0, 2002.

Härer, S., Bernhardt, M., Corripio, J. G., and Schulz, K.: PRACTISE - Photo Rectification And ClassificaTIon SoftwarE (V.1.0), Geosci. Model Dev., 6, 837-848, https://doi.org/10.5194/gmd-6837-2013, 2013.

Härer, S., Bernhardt, M., and Schulz, K.: PRACTISE - Photo Rectification And ClassificaTIon SoftwarE (V.2.1), Geosci. Model Dev., 9, 307-321, https://doi.org/10.5194/gmd-9-3072016, 2016.

Härer, S., Bernhardt, M., Siebers, M., and Schulz, K.: On the need for a time- and location-dependent estimation of the NDSI threshold value for reducing existing uncertainties in snow cover maps at different scales, The Cryosphere, 12, 1629-1642, https://doi.org/10.5194/tc-12-1629-2018, 2018.

Hay, L. E. and Clark, M. P.: Use of statistically and dynamically downscaled atmospheric model output for hydrologic simulations in three mountainous basins in the western United States, J. Hydrol., 282, 56-75, https://doi.org/10.1016/S00221694(03)00252-X, 2003.

Hersbach, H., Bell, W., Berrisford, P., Horányi, A. J. M.-S., Nicolas, J., Radu, R., Schepers, D., Simmons, A., Soci, C., and Dee, D.: Global reanalysis: goodbye ERA-Interim, hello ERA5, European Centre for Medium-Range Weather Forecasts, Reading, UK, https://doi.org/10.21957/VF291HEHD7, 2019.

Hersbach, H., Bell, B., Berrisford, P., Hirahara, S., Horányi, A., Muñoz-Sabater, J., Nicolas, J., Peubey, C., Radu, R., Schepers, D., Simmons, A., Soci, C., Abdalla, S., Abellan, X., Balsamo, G., Bechtold, P., Biavati, G., Bidlot, J., Bonavita, M., Chiara, G., Dahlgren, P., Dee, D., Diamantakis, M., Dragani, R., Flemming, J., Forbes, R., Fuentes, M., Geer, A., Haimberger, L., Healy, S., Hogan, R. J., Hólm, E., Janisková, M., Keeley, S., Laloyaux, P., Lopez, P., Lupu, C., Radnoti, G., Rosnay, P., Rozum, I., Vamborg, F., Villaume, S., and Thépaut, J.-N.: The ERA5 global reanalysis, Q. J. Roy. Meteorol. Soc., 146, 1999-2049, https://doi.org/10.1002/QJ.3803, 2020.

Hirsch, R. M. and Costa, J. E.: U.S. stream flow measurement and data dissemination improve, Eos Trans. AGU, 85, 197-203, https://doi.org/10.1029/2004eo200002, 2004.

Hirtlreiter, G.: Spät- und postglaziale Gletscherschwankungen im Wettersteingebirge und seiner Umgebung: Münchner Geographische Abhandlungen, in: Münchner Geographische Abhandlungen (B), Ludwig-Maximilians-University Munich, Munich, 1992.

Hopkinson, C., Chasmer, L., Munro, S., and Demuth, M. N.: The influence of DEM resolution on simulated solar radiation-induced glacier melt, Hydrol. Process., 24, 775-788, https://doi.org/10.1002/hyp.7531, 2010
Hrachowitz, M. and Weiler, M.: Uncertainty of Precipitation Estimates Caused by Sparse Gauging Networks in a Small, Mountainous Watershed, J. Hydrol. Eng., 16, 460-471, https://doi.org/10.1061/(ASCE)HE.1943-5584.0000331, 2011.

Hrachowitz, M., Savenije, H., Blöschl, G., McDonnell, J. J., Sivapalan, M., Pomeroy, J. W., Arheimer, B., Blume, T., Clark, M. P., Ehret, U., Fenicia, F., Freer, J. E., Gelfan, A., Gupta, H. V., Hughes, D. A., Hut, R. W., Montanari, A., Pande, S., Tetzlaff, D., Troch, P. A., Uhlenbrook, S., Wagener, T., Winsemius, H. C., Woods, R. A., Zehe, E., and Cudennec, C.: A decade of Predictions in Ungauged Basins (PUB) - a review, Hydrolog. Sci. J., 58, 1198-1255, https://doi.org/10.1080/02626667.2013.803183, 2013.

Huggel, C., Carey, M., Clague, J. J., and Kaab, A.: The high-mountain cryosphere: Environmental changes and human risks, Cambridge University Press, Cambridge, https://doi.org/10.1017/CBO9781107588653, 2015.

Hürkamp, K., Zentner, N., Reckerth, A., Weishaupt, S., Wetzel, K.-F., Tschiersch, J., and Stumpp, C.: Spatial and Temporal Variability of Snow Isotopic Composition on Mt. Zugspitze, Bavarian Alps, Germany, J. Hydrol. Hydromech., 67, 49-58, https://doi.org/10.2478/johh-2018-0019, 2019.

Huss, M., Bookhagen, B., Huggel, C., Jacobsen, D., Bradley, R. S., Clague, J. J., Vuille, M., Buytaert, W., Cayan, D. R., Greenwood, G., Mark, B. G., Milner, A. M., Weingartner, R., and Winder, M.: Toward mountains without permanent snow and ice, Earth's Future, 5, 418-435, https://doi.org/10.1002/2016EF000514, 2017.

Hüttl, C.: Steuerungsfaktoren und Quantifizierung der chemischen Verwitterung auf dem Zugspitzplatt (Wettersteingebirge, Deutschland), in: Münchener Geographische Abhandlungen Reihe B, Ludwig-Maximilians-University Munich, Munich, 1999.

Kahl, A., Winstral, A., Marks, D., and Dozier, J.: Using Satellite Imagery and the Distributed ISNOBAL Energy Balance Model to Derive SWE Heterogeneity in Mountainous Basins, in: Putting Prediction in Ungauged Basins into Practice, edited by: Pomeroy, J. W., Whitfield, P. H., and Spence, C., Canadian Water Resources Association, ISBN 978-1-896513-38-6, 2013.

Kim, R. S., Durand, M., and Liu, D.: Spectral analysis of airborne passive microwave measurements of alpine snowpack: Colorado, USA, Remote Sens. Environ., 205, 469-484, https://doi.org/10.1016/j.rse.2017.07.025, 2018.

Koch, F., Bach, H., Prasch, M., Weber, M., Braun, L., and Mauser, W.: Climate Change and Energy - Impact of Snow and Glacier Melting on Hydropower in the Catchment Area of the Upper, Korrespondenz Wasserwirtschaft, 2011, 319-328, 2011.

Koch, F., Henkel, P., Appel, F., Schmid, L., Bach, H., Lamm, M., Prasch, M., Schweizer, J., and Mauser, W.: Retrieval of Snow Water Equivalent, Liquid Water Content, and Snow Height of Dry and Wet Snow by Combining GPS Signal Attenuation and Time Delay, Water Resour. Res., 9, 4465-4487, https://doi.org/10.1029/2018WR024431, 2019.

König-Langlo, G. and Augstein, F.: Parameterization of the downward long-wave radiation at the Earth surface in polar regions, Meteorol. Z., 3, 343-347, 1994.

Konzelmann, T., van de Wal, R., Greuell, W., Bintanja, R., Henneken, E., and Abeouchi, A.: Parameterization of global and longwave incoming radiation for the Greenland Ice Sheet, Global 
Planet. Change, 9, 143-164, https://doi.org/10.1016/09218181(94)90013-2, 1994.

Kundzewicz, Z. W. and Stakhiv, E. Z.: Are climate models "ready for prime time" in water resources management applications, or is more research needed?, Hydrolog. Sci. J., 55, 1085-1089, https://doi.org/10.1080/02626667.2010.513211, 2010.

Kunkel, K. E.: Simple Procedures for Extrapolation of $\mathrm{Hu}-$ midity Variables in the Mountainous Western United States, J. Climate, 2, 656-670, https://doi.org/10.1175/15200442(1989)002<0656:SPFEOH>2.0.CO;2, 1989.

Kwok, R. and Markus, T.: Potential basin-scale estimates of Arctic snow depth with sea ice freeboards from CryoSat-2 and ICESat2: An exploratory analysis, Adv. Space Res., 62, 1243-1250, https://doi.org/10.1016/j.asr.2017.09.007, 2018.

Lettenmaier, D. P., Alsdorf, D., Dozier, J., Huffman, G. J., Pan, M., and Wood, E. F.: Inroads of remote sensing into hydrologic science during the WRR era, Water Resour. Res., 51, 7309-7342, https://doi.org/10.1002/2015WR017616, 2015.

Lievens, H., Demuzere, M., Marshall, H.-P., Reichle, R. H., Brucker, L., Brangers, I., de Rosnay, P., Dumont, M., Girotto, M., Immerzeel, W. W., Jonas, T., Kim, E. J., Koch, I., Marty, C., Saloranta, T., Schöber, J., and de Lannoy, G. J. M.: Snow depth variability in the Northern Hemisphere mountains observed from space, Nat. Commun., 10, 4629, https://doi.org/10.1038/s41467019-12566-y, 2019.

Liston, G. E. and Elder, K.: A Meteorological Distribution System for High-Resolution Terrestrial Modeling (MicroMet), J. Hydrometeorol., 7, 217-234, https://doi.org/10.1175/JHM486.1, 2006.

Liu, S., Mo, X., Liu, C., Xia, J., and Zhao, W.: How to maximize the predictive values of available data in ungauged basins? - Chinese Lesson, in: Putting Prediction in Ungauged Basins into Practice, edited by: Pomeroy, J. W., Whitfield, P. H., and Spence, C., Canadian Water Resources Association, ISBN 978-1-896513-38-6, 2013.

López-Moreno, J. I., Pomeroy, J. W., Revuelto, J., and VicenteSerrano, S. M.: Response of snow processes to climate change: spatial variability in a small basin in the Spanish Pyrenees, Hydrol. Process., 27, 2637-2650, https://doi.org/10.1002/hyp.9408, 2013.

Love, T. B., Kumar, V., Xie, P., and Thiaw, W.: A 20year daily Africa precipitation climatology using satellite and gauge data, in: Proceedings of the 84th AMS Annual Meeting, vol. Conference on Applied Climatology, Seattle, 4 pp., available at: https://www.cpc.ncep.noaa.gov/products/ fews/AFR_CLIM/appl_clim.pdf (last access: 24 May 2021), 2004.

Ludwig, R. and Schneider, P.: Validation of digital elevation models from SRTM X-SAR for applications in hydrologic modeling, ISPRS J. Photogram. Remote Sens., 60, 339-358, https://doi.org/10.1016/j.isprsjprs.2006.05.003, 2006.

Lv, Z., Pomeroy, J. W., and Fang, X.: Evaluation of SNODAS Snow Water Equivalent in Western Canada and Assimilation Into a Cold Region Hydrological Model, Water Resour. Res., 55, 11166-11187, https://doi.org/10.1029/2019WR025333, 2019.

MacDonald, M. K., Pomeroy, J. W., and Pietroniro, A.: On the importance of sublimation to an alpine snow mass balance in the Canadian Rocky Mountains, Hydrol. Earth Syst. Sci., 14, 14011415, https://doi.org/10.5194/hess-14-1401-2010, 2010.
Marks, D., Domingo, J., Susong, D., Link, T., and Garen, D.: A spatially distributed energy balance snowmelt model for application in mountain basins, Hydrol. Process., 13, 1935-1959, https://doi.org/10.1002/(SICI)10991085(199909)13:12/13<1935::AID-HYP868>3.0.CO;2-C, 1999.

Marti, R., Gascoin, S., Berthier, E., de Pinel, M., Houet, T., and Laffly, D.: Mapping snow depth in open alpine terrain from stereo satellite imagery, The Cryosphere, 10, 1361-1380, https://doi.org/10.5194/tc-10-1361-2016, 2016.

Mauser, W., and Prasch, M.: Regional Assessment of Global Change Impacts. The Project GLOWA-Danube, Springer International Publishing, Cham, ISBN 978-3-319-16751-0, https://doi.org/10.1007/978-3-319-16751-0, 2016.

Merwade, V., Olivera, F., Arabi, M., and Edleman, S.: Uncertainty in Flood Inundation Mapping: Current Issues and Future Directions, J. Hydrol. Eng., 13, 608-620, https://doi.org/10.1061/(ASCE)1084-0699(2008)13:7(608), 2008.

Meybeck, M., Green, P., and Vörösmarty, C.: A New Typology for Mountains and Other Relief Classes, Mt. Res. Dev., 21, 34-45, https://doi.org/10.1659/02764741(2001)021[0034:ANTFMA]2.0.CO;2, 2001.

Morche, D. and Schmidt, K. H.: Sediment transport in an alpine river before and after a dambreak flood event, Earth Surf. Proc. Land., 37, 347-353, https://doi.org/10.1002/esp.2263, 2012.

Mott, R., Scipión, D., Schneebeli, M., Dawes, N., Berne, A., and Lehning, M.: Orographic effects on snow deposition patterns in mountainous terrain, J. Geophys. Res.-Atmos., 119, 1419-1439, https://doi.org/10.1002/2013JD019880, 2014.

Muerth, M. J., Gauvin St-Denis, B., Ricard, S., Velázquez, J. A., Schmid, J., Minville, M., Caya, D., Chaumont, D., Ludwig, R., and Turcotte, R.: On the need for bias correction in regional climate scenarios to assess climate change impacts on river runoff, Hydrol. Earth Syst. Sci., 17, 1189-1204, https://doi.org/10.5194/hess-17-1189-2013, 2013.

Muñoz Sabater, J.: ERA5-Land hourly data from 1981 to present, ECMWF, https://doi.org/10.24381/CDS.E2161BAC, 2019.

Nagaveni, C., Kumar, K. P., and Ravibabu, M. V.: Evaluation of TanDEMx and SRTM DEM on watershed simulated runoff estimation, J. Earth Syst. Sci., 128, 73, https://doi.org/10.1007/s12040-018-1035-z, 2019.

Nash, J. E. and Sutcliffe, J. V.: River flow forecasting through conceptual models: Part 1 - A discussion of principles, J. Hydrol., 10, 282-290, 1970.

Niu, G.-Y., Yang, Z.-L., Mitchell, K. E., Chen, F., Ek, M. B., Barlage, M., Kumar, A., Manning, K., Niyogi, D., Rosero, E., Tewari, M., and Xia, Y.: The community Noah land surface model with multiparameterization options (Noah-MP): 1. Model description and evaluation with local-scale measurements, Environ. Res. Lett., 116, D12109, https://doi.org/10.1029/2010JD015139, 2011.

Notarnicola, C.: Hotspots of snow cover changes in global mountain regions over 2000-2018, Remote Sens. Environ., 243, 111781, https://doi.org/10.1016/j.rse.2020.111781, 2020.

Piani, C., Haerter, J. O., and Coppola, E.: Statistical bias correction for daily precipitation in regional climate models over Europe, Theor. Appl. Climatol., 99, 187-192, https://doi.org/10.1007/s00704-009-0134-9, 2010. 
Poli, P., Hersbach, H., Dee, D. P., Berrisford, P., Simmons, A. J., Vitart, F., Laloyaux, P., Tan, D. G. H., Peubey, C., Thépaut, J.-N., Trémolet, Y., Hólm, E. V., Bonavita, M., Isaksen, L., and Fisher, M.: ERA-20C: An Atmospheric Reanalysis of the Twentieth Century, J. Climate, 29, 4083-4097, https://doi.org/10.1175/JCLI-D-15-0556.1, 2016.

Pomeroy, J. W. and Li, L.: Prairie and arctic areal snow cover mass balance using a blowing snow model, J. Geophys. Res., 105, 26619, https://doi.org/10.1029/2000JD900149, 2000.

Pomeroy, J. W., Gray, D. M., Brown, T., Hedstrom, N. R., Quinton, W. L., Granger, R. J., and Carey, S. K.: The cold regions hydrological model: a platform for basing process representation and model structure on physical evidence, Hydrol. Process., 21, 2650-2667, https://doi.org/10.1002/hyp.6787, 2007.

Pomeroy, J. W., Whitfield, P. H., and Spence, C. (Eds.): Putting Prediction in Ungauged Basins into Practice, Canadian Water Resources Association, ISBN 978-1-896513-38-6, 2013.

Rappl, A., Wetzel, K.-F., Büttner, G., and Scholz, M.: Tracerhydrolgische Untersuchungen am Partnach-Ursprung: Dye tracer investigation at the Partnach Spring (German Alps), Hydrol. Water Resour. Manage., 54, 220-230, 2010.

Rodell, M., Houser, P. R., Jambor, U., Gottschalck, J., Mitchell, K., Meng, C.-J., Arsenault, K., Cosgrove, B., Radakovich, J., Bosilovich, M., Entin, J. K., Walker, J. P., Lohmann, D., and Toll, D.: The Global Land Data Assimilation System, B. Am. Meteorol. Soc., 85, 381-394, https://doi.org/10.1175/BAMS-85-3-381, 2004.

Rott, H., Nagler, T., Ripper, E., Voglmeier, K., Prinz, R., Fromm, R., Coccia, A., Meta, A., Di Leo, D., and Schuttemeyer, D.: $\mathrm{KU}$ - and X-band backscatter analysis and SWE retrieval for Alpine snow, in: IEEE International Geoscience and Remote Sensing Symposium (IGARSS), Piscataway, NJ, 2407-2410, https://doi.org/10.1109/IGARSS.2014.6946957, 2014.

Sabatini, F.: Setting up and Managing Automatic Weather Stations for Remote Sites Monitoring: From Niger to Nepal, in: Renewing Local Planning to Face Climate Change in the Tropics, Green Energy and Technology, edited by: Tiepolo, M., Pezzoli, A., and Tarchiani, V., Springer International Publishing, Cham, 21-39, https://doi.org/10.1007/978-3-319-59096-7_2, 2017.

Saha, S., Moorthi, S., Pan, H.-L., Wu, X., Wang, J., Nadiga, S., Tripp, P., Kistler, R., Woollen, J., Behringer, D., Liu, H., Stokes, D., Grumbine, R., Gayno, G., Wang, J., Hou, Y.-T., Chuang, H.Y., Juang, H.-M. H., Sela, J., Iredell, M., Treadon, R., Kleist, D., van Delst, P., Keyser, D., Derber, J., Ek, M., Meng, J., Wei, H., Yang, R., Lord, S., van den Dool, H., Kumar, A., Wang, W., Long, C., Chelliah, M., Xue, Y., Huang, B., Schemm, J.-K., Ebisuzaki, W., Lin, R., Xie, P., Chen, M., Zhou, S., Higgins, W., Zou, C.-Z., Liu, Q., Chen, Y., Han, Y., Cucurull, L., Reynolds, R. W., Rutledge, G., and Goldberg, M.: The NCEP Climate Forecast System Reanalysis, B. Am. Meteorol. Soc., 91, 1015-1058, https://doi.org/10.1175/2010BAMS3001.1, 2010.

Saha, S., Moorthi, S., Wu, X., Wang, J., Nadiga, S., Tripp, P., Behringer, D., Hou, Y.-T., Chuang, H.-Y., Iredell, M., Ek, M., Meng, J., Yang, R., Mendez, M. P., van den Dool, H., Zhang, Q., Wang, W., Chen, M., and Becker, E.: The NCEP Climate Forecast System Version 2, J. Climate, 27, 2185-2208, https://doi.org/10.1175/JCLI-D-12-00823.1, 2014.

Satgé, F., Ruelland, D., Bonnet, M.-P., Molina, J., and Pillco, R.: Consistency of satellite-based precipitation products in space and over time compared with gauge observations and snowhydrological modelling in the Lake Titicaca region, Hydrol. Earth Syst. Sci., 23, 595-619, https://doi.org/10.5194/hess-23595-2019, 2019.

Schattan, P., Baroni, G., Oswald, S. E., Schöber, J., Fey, C., Kormann, C., Huttenlau, M., and Achleitner, S.: Continuous monitoring of snowpack dynamics in alpine terrain by aboveground neutron sensing, Water Resour. Res., 53, 3615-3634, https://doi.org/10.1002/2016WR020234, 2017.

Sedlar, J. and Hock, R.: Testing longwave radiation parameterizations under clear and overcast skies at Storglaciären, Sweden, The Cryosphere, 3, 75-84, https://doi.org/10.5194/tc-3-75-2009, 2009.

Seyler, F., Muller, F., Cochonneau, G., Guimarães, L., and Guyot, J. L.: Watershed delineation for the Amazon sub-basin system using GTOPO30 DEM and a drainage network extracted from JERS SAR images, Hydrol. Process., 23, 3173-3185, https://doi.org/10.1002/hyp.7397, 2009.

Shaw, T. E., Gascoin, S., Mendoza, P. A., Pellicciotti, F., and McPhee, J.: Snow Depth Patterns in a High Mountain Andean Catchment from Satellite Optical Tristereoscopic Remote Sensing, Water Resour. Res., 56, e2019WR024880, https://doi.org/10.1029/2019WR024880, 2020.

Sheffield, J., Goteti, G., and Wood, E. F.: Development of a 50Year High-Resolution Global Dataset of Meteorological Forcings for Land Surface Modeling, J. Climate, 19, 3088-3111, https://doi.org/10.1175/JCLI3790.1, 2006.

Shi, J. and Dozier, J.: Mapping seasonal snow with SIR-C/X-SAR in mountainous areas, Remote Sens. Environ., 59, 294-307, https://doi.org/10.1016/S0034-4257(96)00146-0, 1997.

Shi, J. and Dozier, J.: Estimation of snow water equivalence using SIR-C/X-SAR. I. Inferring snow density and subsurface properties, IEEE T. Geosci. Remote, 38, 2465-2474, https://doi.org/10.1109/36.885195, 2000.

Smiatek, G., Kunstmann, H., Knoche, R., and Marx, A.: Precipitation and temperature statistics in high-resolution regional climate models: Evaluation for the European Alps, J. Geophys. Res., 114, D19107, https://doi.org/10.1029/2008JD011353, 2009.

Sørensen, R. and Seibert, J.: Effects of DEM resolution on the calculation of topographical indices: TWI and its components, J. Hydrol., 347, 79-89, https://doi.org/10.1016/j.jhydrol.2007.09.001, 2007.

Tadono, T., Ishida, H., Oda, F., Naito, S., Minakawa, K., and Iwamoto, H.: Precise Global DEM Generation by ALOS PRISM, ISPRS Ann. Photogram. Remote Sens. Spat. Inform. Sci., II-4, 71-76, https://doi.org/10.5194/isprsannals-II-4-71-2014, 2014.

Tauro, F., Selker, J., van de Giesen, N., Abrate, T., Uijlenhoet, R., Porfiri, M., Manfreda, S., Caylor, K., Moramarco, T., Benveniste, J., Ciraolo, G., Estes, L., Domeneghetti, A., Perks, M. T., Corbari, C., Rabiei, E., Ravazzani, G., Bogena, H., Harfouche, A., Brocca, L., Maltese, A., Wickert, A., Tarpanelli, A., Good, S., Lopez Alcala, J. M., Petroselli, A., Cudennec, C., Blume, T., Hut, R., and Grimaldi, S.: Measurements and Observations in the XXI century (MOXXI): innovation and multi-disciplinarity to sense the hydrological cycle, Hydrolog. Sci. J., 63, 169-196, https://doi.org/10.1080/02626667.2017.1420191, 2018.

Teutschbein, C., Wetterhall, F., and Seibert, J.: Evaluation of different downscaling techniques for hydrological climate-change 
impact studies at the catchment scale, Clim. Dynam., 37, 20872105, https://doi.org/10.1007/s00382-010-0979-8, 2011.

Thornton, P. E., Running, S. W., and White, M. A.: Generating surfaces of daily meteorological variables over large regions of complex terrain, J. Hydrol., 190, 214-251, https://doi.org/10.1016/S0022-1694(96)03128-9, 1997.

USGS: GTPO30 Global Digital Elevation Model, available at: https://www.usgs.gov/centers/eros/science/usgs-eros-archivedigital-elevation-global-30-arc-second-elevation (last access: 24 May 2021), 1996.

van de Giesen, N., Hut, R., and Selker, J.: The Trans-African Hydro-Meteorological Observatory (TAHMO), Wiley Interdisciplin. Rev.: Water, 1, 341-348, https://doi.org/10.1002/wat2.1034, 2014.

Vaze, J., Teng, J., and Spencer, G.: Impact of DEM accuracy and resolution on topographic indices, Environ. Model. Softw., 25, 1086-1098, https://doi.org/10.1016/j.envsoft.2010.03.014, 2010.

Viviroli, D., Archer, D. R., Buytaert, W., Fowler, H. J., Greenwood, G. B., Hamlet, A. F., Huang, Y., Koboltschnig, G., Litaor, M. I., López-Moreno, J. I., Lorentz, S., Schädler, B., Schreier, H., Schwaiger, K., Vuille, M., and Woods, R.: Climate change and mountain water resources: overview and recommendations for research, management and policy, Hydrol. Earth Syst. Sci., 15, 471-504, https://doi.org/10.5194/hess-15-471-2011, 2011.

Vuyovich, C. M., Jacobs, J. M., and Daly, S. F.: Comparison of passive microwave and modeled estimates of total watershed SWE in the continental United States, Water Resour. Res., 50, 90889102, https://doi.org/10.1002/2013WR014734, 2014.

Weber, M., Bernhardt, M., Pomeroy, J. W., Fang, X., Härer, S., and Schulz, K.: Description of current and future snow processes in a small basin in the Bavarian Alps, Environ. Earth Sci., 75, 962, https://doi.org/10.1007/s12665-016-6027-1, 2016.

Weber, M., Feigl, M., Schulz, K., and Bernhardt, M.: On the Ability of LIDAR Snow Depth Measurements to Determine or Evaluate the HRU Discretization in a Land Surface Model, Hydrology, 7, 20, https://doi.org/10.3390/hydrology7020020, 2020.
Wesemann, J., Herrnegger, M., and Schulz, K.: Hydrological modelling in the anthroposphere: predicting local runoff in a heavily modified high-alpine catchment, J. Mount. Sci., 15, 921-938, https://doi.org/10.1007/s11629-017-4587-5, 2018.

Wetzel, K.-F.: On the Hydrology of the Partnach Area in the Wetterstein Mountains (Bavarian Alps), Erdkunde, 58, 172-186, https://doi.org/10.3112/erdkunde.2004.02.05, 2004.

Whitfield, P. H., Moore, R. D., and Shook, K.: Summary and Synthesis of Workshop Break Out Group Discussions, in: Putting Prediction in Ungauged Basins into Practice, edited by: Pomeroy, J. W., Whitfield, P. H., and Spence, C., Canadian Water Resources Association, ISBN 978-1-896513-38-6, 271-304, 2013.

Winstral, A., Elder, K., and Davis, R. E.: Spatial Snow Modeling of Wind-Redistributed Snow Using Terrain-Based Parameters, J. Hydrometeorol., 3, 524-538, https://doi.org/10.1175/15257541(2002)003<0524:SSMOWR>2.0.CO;2, 2002.

WMO: Technical regulations: Basic documents no. 2: Volume I General Meteorological Standards and Recommended Practices, 2010th Edn., World Meteorological Organization, Geneva, 2011.

Wortmann, M., Bolch, T., Menz, C., Tong, J., and Krysanova, V.: Comparison and Correction of High-Mountain Precipitation Data Based on Glacio-Hydrological Modeling in the Tarim River Headwaters (High Asia), J. Hydrometeorol., 19, 777-801, https://doi.org/10.1175/JHM-D-17-0106.1, 2018.

Wrobel, J.-P.: Berichtüber den Markierungsversuch auf dem Zugspitzplatt im Sommer 1980, Bayerisches Geologisches Landesamt, München, 1-6, 1980.

Zhang, F., Zhang, H., Hagen, S. C., Ye, M., Wang, D., Gui, D., Zeng, C., Tian, L., and Liu, J.: Snow cover and runoff modelling in a high mountain catchment with scarce data: effects of temperature and precipitation parameters, Hydrol. Process., 29, 52-65, https://doi.org/10.1002/hyp.10125, 2015. 